\title{
Design and Performance of Feed Delivery Systems for Simulated Radioactive Waste Slurries
}

J. M. Perez, Jr.

February 1983

Prepared for the U.S. Department of Energy under Contract DE-AC06-76RLO 1830

Pacific Northwest Laboratory Operated for the U.S. Department of Energy by Battelle Memorial Institute 


\title{
DISCLAIMER
}

This report was prepared as an account of work sponsored by an agency of the United States Government. Neither the United States Government nor any agency thereof, nor any of their employees, makes any warranty, express or implied, or assumes any legal liability or responsibility for the accuracy, completeness, or usefulness of any information, apparatus, product, or process disclosed, or represents that its use would not infringe privately owned rights. Reference herein to any specific commercial product, process, or service by trade name, trademark, manufacturer, or otherwise, does not necessarily constitute or imply its endorsement, recommeridation, or favoring by the United States Government or any agency thereof. The views and opinions of authors expressed herein do not necessarily state cr reflect those of the United States Government or any agency thereof.

\author{
PACIFIC NORTHWEST I.ABORATORY \\ operated by \\ BATTELLE \\ for the \\ UNITED STATES DEPARTMENT OF ENERGY \\ under Contract DE-AC06-76RLO 1830
}

\begin{tabular}{|c|c|}
\hline \multirow{2}{*}{\multicolumn{2}{|c|}{ Printed in the United States of America }} \\
\hline & \\
\hline \multirow{4}{*}{\multicolumn{2}{|c|}{$\begin{array}{c}\text { National Technical Information Service } \\
\text { United States Department of Commerce } \\
5285 \text { Port Roval Road } \\
\text { Springfield, Virginia } 22151\end{array}$}} \\
\hline & \\
\hline & \\
\hline & \\
\hline \multirow{2}{*}{\multicolumn{2}{|c|}{$\begin{array}{l}\text { NTIS Price Codes } \\
\text { Microfiche A01 }\end{array}$}} \\
\hline & \\
\hline \multicolumn{2}{|c|}{ Printed Copy } \\
\hline & Price \\
\hline Pages & Codes \\
\hline $001-025$ & $\mathrm{~A} 02$ \\
\hline $026-050$ & $\mathrm{~A} 03$ \\
\hline 051-075 & A04 \\
\hline $076-100$ & A05 \\
\hline $161-125$ & $\mathrm{~A} 06$ \\
\hline $126-150$ & $\mathrm{~A} 07$ \\
\hline 151.175 & $A 0 B$ \\
\hline $176-200$ & A09 \\
\hline $201-225$ & A010 \\
\hline $226-250$ & A011 \\
\hline $251-275$ & A012 \\
\hline $276-300$ & A013 \\
\hline
\end{tabular}


PNL -4423

UC-70

DESIGN AND PERFORMANCE OF FEED DELIVERY SYSTEMS FOR SIMULATED RADI OACTIVE WASTE SLURRIES

J. M. Perez, Jr.

February 1983

Prepared for the U.S. Department of Energy under Contract DE-AC06-76RLO 1830

Pacific Northwest Laboratory

Richland, Washington 99352 


\section{ACKNOWLEDGMENTS}

The author would like to thank W. J. Bjorklund, R. A. Brouns, R. D. Dierks, and F. A. Miller for their assistance and many helpful comments in writing this document. 
-

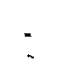

$\because$
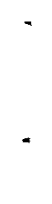


\section{SUMMARY}

Processes for vitrifying simulated high-level radioactive waste have been developed at the Pacific Northwest Laboratory (PNL) over the last several years. Paralleling this effort, several feed systems used to deliver the simulated waste slurry to the melter have been tested.

Because there had been little industrial experience in delivering abrasive slurries at feed rates of less than $10 \mathrm{~L} / \mathrm{min}$, early experience helped direct the design of more dependable systems. Also, as feed delivery requirements changed, the feed system was modified to meet these new requirements. The various feed systems discussed in this document are part of this evolutionary process, so they have not been ranked against each other.

The first system was a cantilevered, centrifugal-pump system which circulated slurry through primary and secondary recirculation loops. Feed was supplied to a large-scale spray calciner through a feed line attached to the primary recirculation loop. During 1830 hours of experimental use, the feed system supplied $\sim 390,000 \mathrm{~L}$ of simulated wastes to the calciner. The system worked well for transferring the relatively dilute waste slurries. However, because of high velocities in the pump housing and line, pipe and equipment wear was unacceptably high. Harder construction materials would wear better.

The idea of using an airlift to move the slurry into the melter was tested next. Two designs were used. The first airlift was a feed slurry metering device only, the head pot being supplied with slurry by a pump and recirculation loop system. The second airlift system was a complex, four-stage system that transferred slurry completely by airlift. While both airlifts effectively lifted and metered feed into the melters, feed traveling through the overflow return lines and horizontal sections was prone to drying and settling. Modifying the design should improve the operation of any airlift systems.

The third type of feed system was a pressurized recirculation loop system that utilized a positive displacement diaphragm pump. By controlling the 
pressure within the recirculation loop, the amount of slurry entering an attached feed line could be controlled. Because the flow velocity within the recirculation loop was reduced, no significant equipment wear occurred, even though the slurries contained $-350 \mathrm{~g} / \mathrm{L}$ of glass frit. This system performed well during five separate experiments totaling $\sim 550$ hours, in which more than $42,000 \mathrm{~L}$ of simulated wastes and glass formers were fed to the vitrification equipment.

The last feed system tested was a variable speed, positive-displacement pump system that delivered feed directly to a melter, eliminating the need for a recirculation loop. This system was reliable in pumping slurries at rates $>1.0 \mathrm{~kg} / \mathrm{min}$. However, at rates $<1.0 \mathrm{~kg} / \mathrm{min}$, or with slurries containing very fast-settling solids, plugging occurred in the flowmeter. Many of the plugs were caused by foreign material such as wood splinters or small stones which entered the feed system. 
CONTENTS

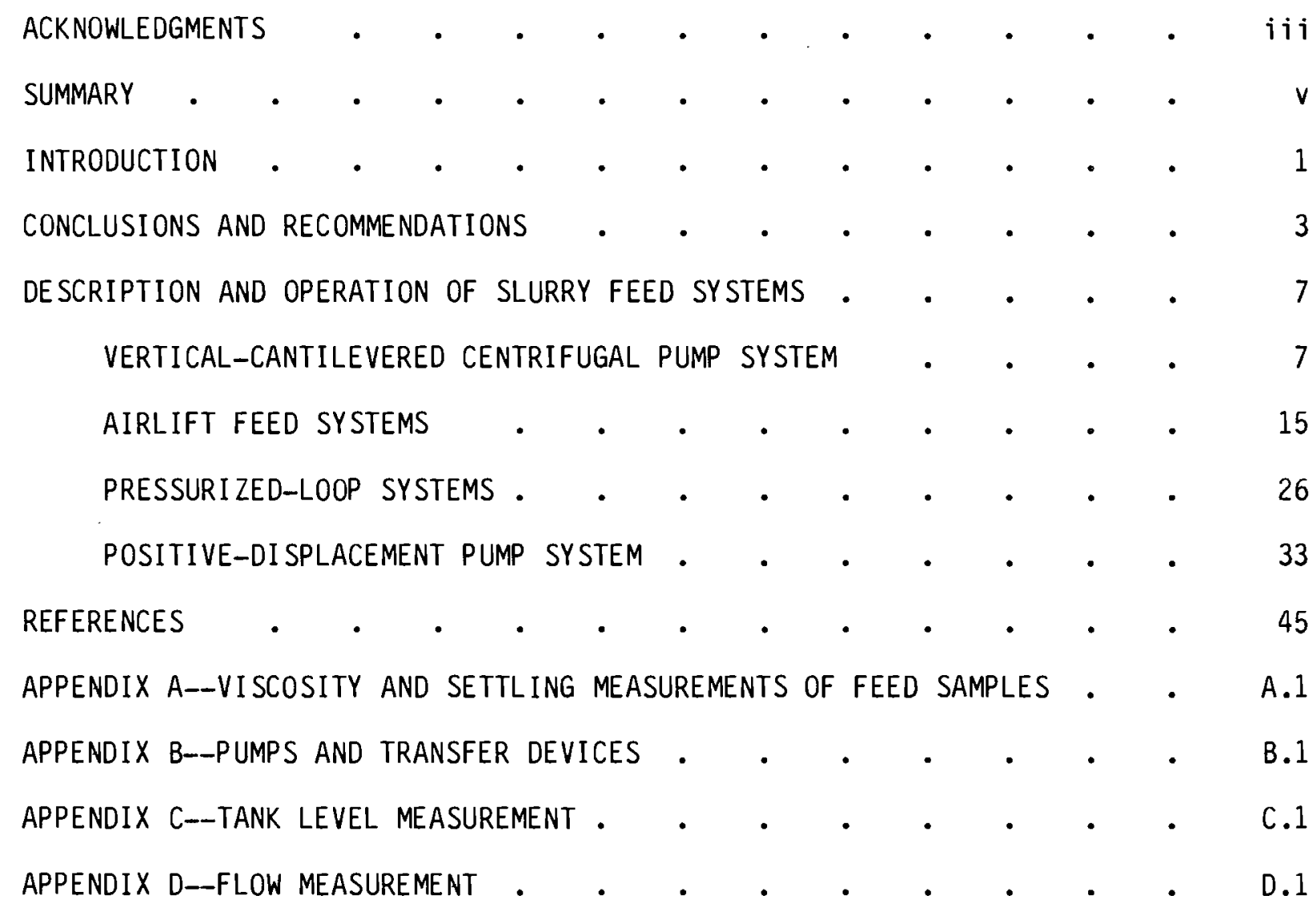




\section{FIGURES}

1 Vertical-Cantilevered Centrifugal Pump Feed System . . . . 8

2 Eroded Ball and Retainer Collar from 2-in. Ball Valve Removed from Secondary Recirculation Loop . • . . • . . 12

3 Eroded 2-in. Ball Valve Removed from Secondary Recirculation Loop . 13

4 Eroded Ball from 1-in. Ball Valve Removed from Primary Recirculation Loop •

5 Typical Airlift Configuration . . . . . . . . . . 16

6 Feed System with Airlift Feed Metering . . • • . . 17

7 Airlift System for Slurries . . . . . . . . . . 20

8 Plexiglass Head Pot--PSCM Airlift System • • • • • . 21

9 Dried Solids Accumulation Inside a Recirculation/Overflow Return Line • • • • • • • • • • • • • 23

10 Dried Solids Collected from Recirculation/Overflow Return Lines . 24

11 Samples of Solids Collected from Recirculation/Overflow Return Line • • • • • • • • • • • • • 25

12 Positive-Displacement Pump-Loop System with Metering System • • 27

13 Positive-Displacement Pump-Loop System Utilizing Air-Operated "Pinch" Valve . . . . . . . . . . . 29

14 Feed Rate Versus Time: PSCM-5 Experiment . . . . . 34

15 Positive-Displacement Pump System . . . . . . . 36

16 Installed Positive-Displacement Pump System . . • . • 37

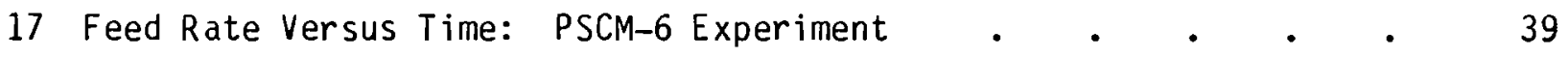

18 Feed Rate Versus Time: PSCM-9 Experiment . . • . . 44

B.1 Flow Characteristics of Centrifugal Pumps . • • . • B.2

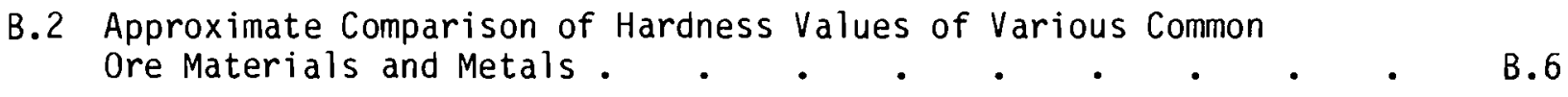


TABLES

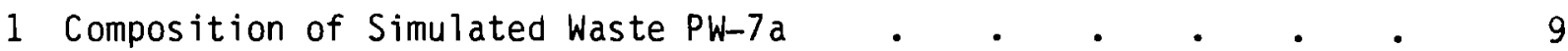

2 Composition of SRP-Simulated Defense Waste . . . . . . 10

3 Composition of Simulated TDS Waste Sludge and Frit-211 . . . 11

4 Composition of Simulated TOS Waste Sludge and Frit-211 • $\quad$ • $\quad 18$

5 Composition of Simulated TOS Waste Sludge and Frit-131 • • • 22

6 Composition of Simulated TDS Formic Acid Waste and Frit-131 • $\quad 32$

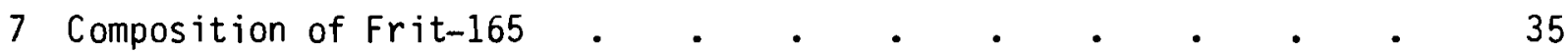

\begin{tabular}{l}
8 Composition of 50 wt\% Simulated TOS Formic Acid Waste and \\
Frit-165 \\
\hline
\end{tabular}

9 Composition of Simulated TDS Hi-Al-Formic Acid Waste and Frit-165 • 42

10 Composition of Simulated West Valley Neutralized Waste and Frit-131 . . . . . . . . . . . . . 43

A.1 Viscosity and Settling Measurements of Feed Samples . • - A.2 


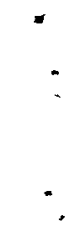


INTRODUCTION

Vitrification equipment for processing simulated high-level radioactive waste slurries has been tested at Pacific Northwest Laboratory for several years. Using several feed compositions and slurry delivery systems, the spray calciners and liquid fed melters were supplied with more than 475,000 L of slurry during more than 3700 hours of operation.

Development of a system to deliver an abrasive slurry at controlled feed rates of less than $10 \mathrm{~L} /$ min has been an evolving process. Experience gained from early feed systems was used to design more dependable systems. Therefore, it is not expected that the various feed systems be ranked against one another. We reviewed the problems that were encountered with slurry feed systems and the steps taken to solve those problems, to better understand the design criteria that need to be considered when designing a slurry feed system.

The four basic types of feed systems designed for nonradioactive testing were 1) a cantilevered centrifugal pump system, 2) airlift feed systems, 3) a positive-displacement pump system, and 4) a variable speed, positivedisplacement pump system. System descriptions and operating experience with these systems are presented in this report, as well as design recommendations. Information pertaining to feed slurry viscosities, settling rate, equipment selection, construction materials, tank level measurement devices and flowmeters is also included. 


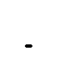

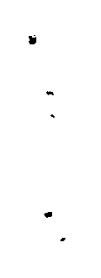




\section{CONCLUSIONS AND RECOMMENDATIONS}

The vertical-cantilevered centrifugal pump system worked well for transferring relatively dilute feed compositions. However, unacceptably high pipe and equipment wear did occur because of high fluid velocities maintained in the recirculation loops. The ball valves and pump-impeller housing were especially worn. There was some plugging in the primary recirculation loop, in-line strainer and feed line caused by settling and oversized particles and feed "lumps" passing out of the feed tank.

From the experience gained with this feed system it is recommended that:

- hard materials be used for construction to minimize abrasion and erosion in pumps. If centrifugal pumps are used, rpm rates should be reduced by minimizing head requirements.

- pumps be chosen that do not require shaft seals, which eliminates or greatly reduces the chance of leaking feed or dilution of the feed by seal flush water. Vertical-cantilevered centrifugal pumps and diaphragm pumps meet this requirement. (Diaphragm pumps can be constructed with a metal diaphragm or radiation resistant elastomer for radioactive slurries.)

- dished-bottomed or conical-bottomed tanks be used with proper agitation to lessen the settling of solids.

- tank filters and/or in-line filters be installed to keep oversized solids and feed "lumps" from plugging the feed system.

The conclusion and recommendations for the two airlift systems follow. Problems arose in the piping system of the first airlift system, al though the airlift effectively metered feed into the melter. Flow rates from the head pot to the airlift line were insufficient to maintain the solids in suspension, resulting in plugging. Plugging in the horizontal sections of the overflow line occurred for the same reason. 
In the second slurry airlift, sections of the airlift system functioned very well. However, the gravity-drain feed line to the melter and the recirculation/overflow return lines from the head pots were susceptible to feed-caking problems during one run.

The use of airlifts is promising, especially for acid waste slurries. They do not require mechanical equipment that needs servicing and repair. Recommended design criteria are:

- maintain high fluid velocities in the lines connecting the head pots and airlift lines and thus prevent settling, ensuring turbulence by high volumetric flows and minimum pipe diameters.

- minimize required horizontal pipe lengths.

- use air sparges at the bottoms of airlift legs to keep solids suspended.

- design head pots to provide separate vents for the feed recirculation/overflow return line and the airlift air.

- use humidified air or inert gas to lessen drying.

- design the recirculation/overflow return line with a minimum pipe diameter to reduce the surface area available for drying.

- ensure that feed is regularly flowing through the recirculation/ overflow return lines by increasing the volumetric flow rates to the head pots. This eliminates cyclic wetting and drying.

The third type of feed system tested, a pressurized recirculation loop, proved initially unacceptable. The system's flexible tubing was easily worn and cut by the abrasive slurry particles, and the pumps could not maintain constant feed rates to the melter because of fluctuating recirculation line pressures. However, a modified system design to use an air-operated "pinch" valve in the return side of the recirculation loop performed quite well during five experiments. Feedback signals from a mass flowmeter sensor located in the feed line controlled the valve action. During the experiments $>42,000 \mathrm{~L}$ of a formic acid slurry composition containing $\sim 480 \mathrm{~g}$ oxide/L slurry were fed to the melters. Feed rates were maintained within $\pm 3 \%$ of setpoint values. 
Therefore, in pressurized recirculation systems, a "pinch" valve should be used to regulate feed rates. Since recirculation rates in the recirculation loop are moderate $(20 \mathrm{~L} / \mathrm{min})$, the slurry does not cause extreme abrasion or wear.

The final system designed was a positive-displacement pump system delivering slurry directly to the pilot scale ceramic melter (PSCM). The system reliably pumped slurries at rates $>1.0 \mathrm{~kg} / \mathrm{min}$, al though at rates $<1.0 \mathrm{~kg} / \mathrm{min}$ or when very fast-settling solids were present, plugging of the flowmeter did occur.

Work with this feed system has shown that adequate feed tank agitation is possible with a pulsed-agitation system that withdraws slurry and then reinjects it into the tank. Also, where the feed tank is located close to the melter, a variable-speed, positive-displacement pump system is recommended.

Noncontacting level measurement devices such as ultrasonics, radar, radiation and load cells for radioactive slurries are also recommended. Air bubbler (air purge) devices are not recommended because they have experienced severe plugging problems with simulated feed slurries.

External measuring flowmeters with no moving parts and relatively low pressure drops (i.e., large orifices), such as magnetic flowmeters or mass flowmeters, should be used.

Finally, since feed viscosities tend to increase with increasing temperature, the feed slurry should be as cool as is practical. This will minimize pumping requirements. 
- 


\section{DESCRIPTION AND OPERATION OF SLURRY FEED SYSTEMS}

The four basic feed systems tested at PNL using simulated high-level radioactive waste slurries were:

- a vertical-cantilevered centrifugal pump system with primary and secondary recirculation loops to supply feed to the full-scale spray calciner

- airlift systems used as a feed-metering device and a complete feed transfer system

- a pressurized loop system with a positive displacement pump and recirculation loop with feed control supplied either by a metering pump or by an air-operated "pinch" valve

- a variable-speed, positive-displacement pump system delivering feed directly to the melter.

Experience with each of these systems and an analys is of their development will be discussed in the following sections.

\section{VERTICAL-CANTILEVERED CENTRIFUGAL PUMP SYSTEM}

A schematic of this system is shown in Figure 1. Feed was discharged from a feed-storage tank by a Corcoran Series 3000 vertical-cantilevered pump. Pump capacity was rated at $57 \mathrm{~L} / \mathrm{min}(15 \mathrm{gal} / \mathrm{min}$ ) at $3102 \mathrm{~mm} \mathrm{Hg}$ (60 psig) and $1750 \mathrm{rpm}$. After leaving the pump discharge, the feed traveled either through the $5.1-\mathrm{cm}$ (2-in.) secondary recirculation loop or the 2.5-cm (1-in.) primary recirculation loop. By manually adjusting the ball valve placed in the $5.1-\mathrm{cm}(2-$ in.) line, the pressure in this line was controlled and the quantity of slurry directed through the primary feed loop was regulated. The above arrangement allowed for the testing of a wide range of feed rates and feed compositions. Coming off the primary recirculation loop was the feed line to the full-scale spray calciner. Flow through this line was adjusted by controlling the pressure drop across a control valve located on the primary recirculation loop. 


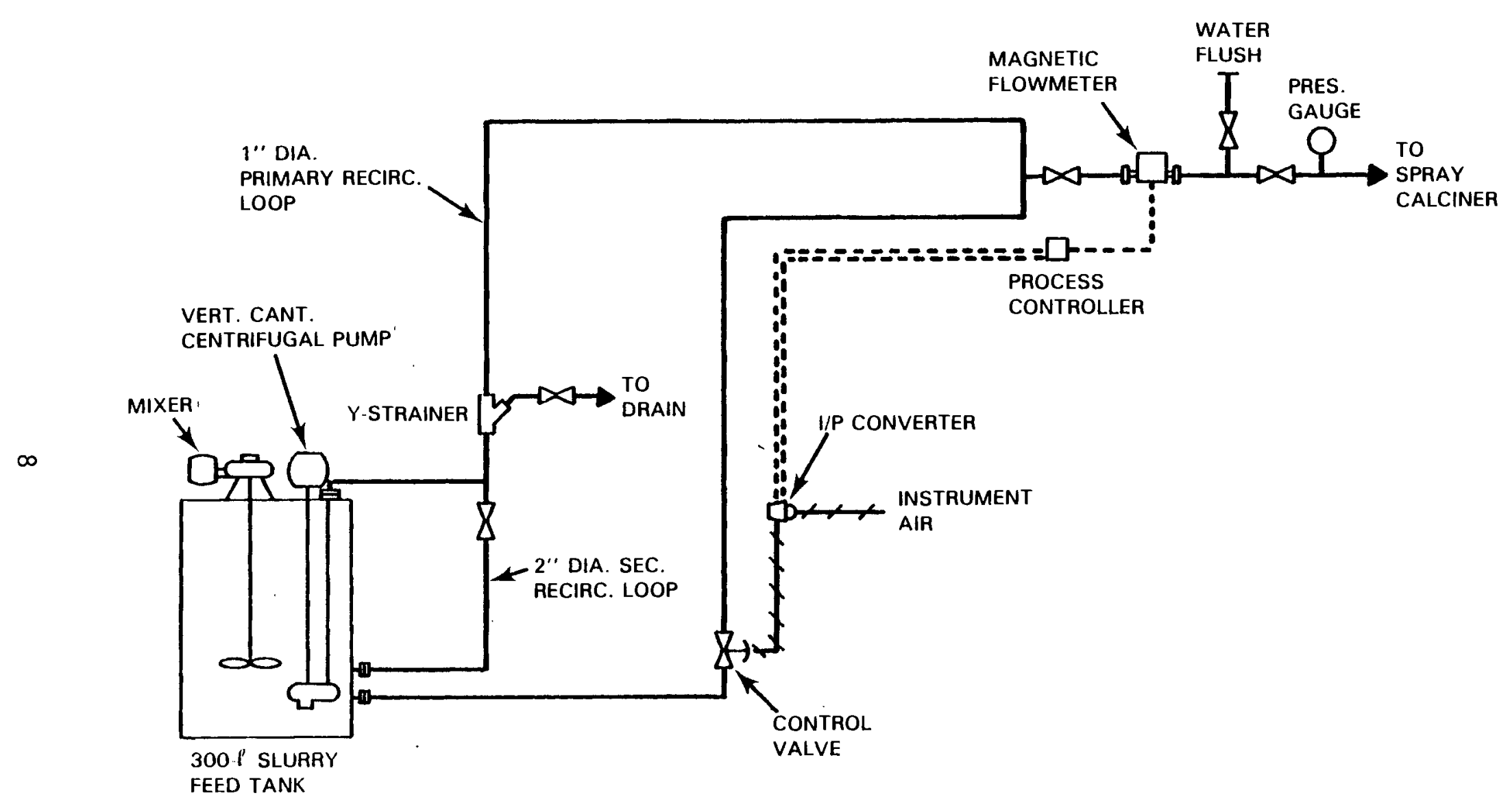

FIGURE 1. Vertical-Cantilevered Centrifugal Pump Feed System 
The vertical-cantilevered centrifugal pump system was used extensively during the full-scale spray calciner development program (Miller 1981) over a period of four years. During this time, 43 processing runs were conducted, logging 1830 hours of feeding time. Many feed compositions were pumped through the system as different waste formulations were studied, but only three main feed compositions were tested. The first, shown in Table 1, was

TABLE 1. Composition of Simulated Waste $\mathrm{PW}-7 \mathrm{a}$

\begin{tabular}{|c|c|}
\hline Component & $W t \%$ \\
\hline $\mathrm{KNO}_{3}$ & 1.52 \\
\hline $\mathrm{NaNO}_{3}$ & 11.17 \\
\hline $\mathrm{Sr}\left(\mathrm{NO}_{3}\right)_{2}$ & 1.34 \\
\hline $\mathrm{Ba}\left(\mathrm{NO}_{3}\right)_{2}$ & 1.65 \\
\hline $\mathrm{Co}\left(\mathrm{NO}_{3}\right)_{2} \cdot 6 \mathrm{H}_{2} \mathrm{O}$ & 3.06 \\
\hline $\mathrm{MoO}_{3}$ & 3.94 \\
\hline $\mathrm{Fe}\left(\mathrm{NO}_{3}\right)_{3} \cdot 9 \mathrm{H}_{2} \mathrm{O}$ & 15.05 \\
\hline $\mathrm{Co}\left(\mathrm{NO}_{3}\right)_{2} \cdot 6 \mathrm{H}_{2} \mathrm{O}$ & 0.68 \\
\hline $\mathrm{Ni}\left(\mathrm{NO}_{3}\right)_{2} \cdot 6 \mathrm{H}_{2} \mathrm{O}$ & 2.53 \\
\hline $\mathrm{TeO}_{2}$ & 0.45 \\
\hline $\mathrm{H}_{3} \mathrm{PO}_{4}(75 \mathrm{wt} \%)$ & 4.59 \\
\hline $\mathrm{Cr}\left(\mathrm{NO}_{3}\right)_{3} \cdot 9 \mathrm{H}_{2} \mathrm{O}$ & 1.13 \\
\hline $\mathrm{Cd}\left(\mathrm{NO}_{3}\right)_{2} \cdot 2 \mathrm{H}_{2} \mathrm{O}$ & 0.14 \\
\hline $\mathrm{AgNO}_{3}$ & 0.08 \\
\hline Rare Earth Nitrate $(\mathrm{a})$ & 34.23 \\
\hline Didymium Carbonate ${ }^{(b)}$ & 17.93 \\
\hline
\end{tabular}

(a) Commercial rare earth mix nominal oxide composition: $0.2 \% \mathrm{Y}_{2} \mathrm{O}_{3}, 24 \%$ $\mathrm{La}_{2} \mathrm{O}_{3}, 48 \% \mathrm{CeO}_{2}, 5 \% \mathrm{Pr}_{6} \mathrm{O}_{11}, 17 \%$ $\mathrm{Nd}_{2} \mathrm{O}_{3}, 3 \% \mathrm{Sm}_{2} \mathrm{O}_{3}, 2 \% \mathrm{Gd}_{2} \mathrm{O}_{3}$ and $0.8 \%$ other rare earth oxides.

(b) Commercial didymium nominal oxide compositions: $4 \% \mathrm{Y}_{2} \mathrm{O}_{3}, 37 \% \mathrm{La}_{2} \mathrm{O}_{3}$, $2 \% \mathrm{CeO}_{2}, 10 \% \operatorname{Pr}_{6} \mathrm{O}_{11}, 36 \% \mathrm{Nd}_{2} \mathrm{O}_{3}$, $5 \% \mathrm{Sm}_{2} \mathrm{O}_{3}, 4 \% \mathrm{Gd}_{2} \mathrm{O}_{3}, 2 \% \mathrm{Dy}_{2} \mathrm{O}_{3}$, $0.2 \% \mathrm{Ho}_{2} \mathrm{O}_{3}, 0.4 \% \mathrm{Er}_{2} \mathrm{O}_{3}$, and less than $0.1 \%$ of each other rare earth oxides. 
PW-7a, a simulated acidic power reactor waste. Solids loadings in the slurries $r$ an as high as 173 g-oxide/L of solution. There were no recorded feed stoppages attributed to a feed system failure during the first $\sim 345$ hours of operation spread over 16 runs. One run accounting for 252 hours used a feed with a solids loading of $\sim 150$ g-oxide/L.

Savannah River Plant (SRP) simulated alkaline defense waste was the next type of feed tested. Its composition is listed in Table 2. Solids loadings in this feed ranged from 60 to $90 \mathrm{~g}$-oxide/L. Twelve experiments, using this feed composition or a variation of it, logged a total of 355 hours of feeding time. During one experiment accounting for $\sim 213$ hours, no major feed system component failures were noted; however, three hours of downtime were logged because of blockages in the primary recirculation loop, the in-line strainer, and the feed line itself. These blockages were due mainly to oversized particles and feed "lumps" passing out of the feed tank.

The third and final major feed composition, comprising 14 runs and $\sim 1100$ hours, was SRP-TDS-simulated waste and Frit-211 (Table 3). The oxide loading in the TDS waste varied from 46 to $144 \mathrm{~g}$-oxide/L. All but one of the tests with the TDS composition, however, did not include the glass frit in the slurry feed stream. The first major system failures surfaced after the system had operated for nearly 1000 hours during a long, 504-hour test. The abrasive action of the particles eroded the feed system piping and caused two separate

TABLE 2. Composition of SRP-Simulated Defense Waste

\begin{tabular}{lr} 
Component & Fe $\%$ \\
\cline { 1 - 1 } $\mathrm{Al}(\mathrm{OH})_{3}$ & 53.7 \\
$\mathrm{MnO}_{2}$ & 13.5 \\
$\mathrm{CaCO}_{3}$ & 10.7 \\
$\mathrm{NiO}_{3} \cdot \mathrm{H}_{2} \mathrm{O}$ & 4.9 \\
$\mathrm{NaNO}_{3}$ & 5.8 \\
$\mathrm{Na}_{2} \mathrm{SO}_{4}$ & 2.25 \\
Zeolite & 1.12
\end{tabular}




\section{TABLE 3. Composition of Simulated TDS}

Waste Sludge and Frit-211

\begin{tabular}{lr} 
Component & Wt\% \\
\cline { 3 - 3 } $\mathrm{Fe}(\mathrm{OH})_{3}$ & 53.2 \\
$\mathrm{Al}(\mathrm{OH})_{3}$ & 13.3 \\
$\mathrm{MnO}_{2}$ & 10.6 \\
$\mathrm{CaCO}_{3}$ & 4.8 \\
$\mathrm{NiO}_{3} \mathrm{H}_{2} \mathrm{O}$ & 6.9 \\
$\mathrm{NaNO}_{3}$ & 2.2 \\
$\mathrm{Na}_{2} \mathrm{SO}_{4}$ & 1.1 \\
$\mathrm{ZeOlite}$ & 7.9
\end{tabular}

leaks in the secondary feed recirculation line. This line is used to throttle the flow rate through the primary loop (see Figure 1). The abrasive particles also eroded holes through the wall of the $2-i n$. ball valve and through the threaded section of the recirculation line attached to the valve. Subsequent inspections of the centrifugal pump, pipe elbows and other ball valves also indicated abrasive wear from the feed. Figures 2 and 3 show the eroded $2-i n$. ball valve; Figure 4 is a picture of the ball removed from a 1 -in. ball valve in the primary loop.

The oxide loading for this run was not excessively high at 65 g-oxide/L. Each run probably contributed some to the erosion of the lines and valves. The fluid velocities $(3.1$ to $12.2 \mathrm{~m} / \mathrm{s}$, or 10 to $40 \mathrm{ft} / \mathrm{s}$ ) through the stainless steel recirculation lines were great enough to impinge the solids against the piping and valves with enough force to cause erosion. Appendix $B$ discusses material wear in depth, especially as related to pump components and appropriate preventive measures.

This feed system was operated during a 57-hour co-calcination run in which frit was mixed in the calciner feed slurry. The feed was concentrated to $357 \mathrm{~g}$-oxide/L. Due to the short period of the run no extraordinary pipe or equipment wear was reported. However, frequent losses in feed slurry pressure, measured at the calciner, did occur. These pressure losses were from suspended particles in the viscous feed settling out in the long 


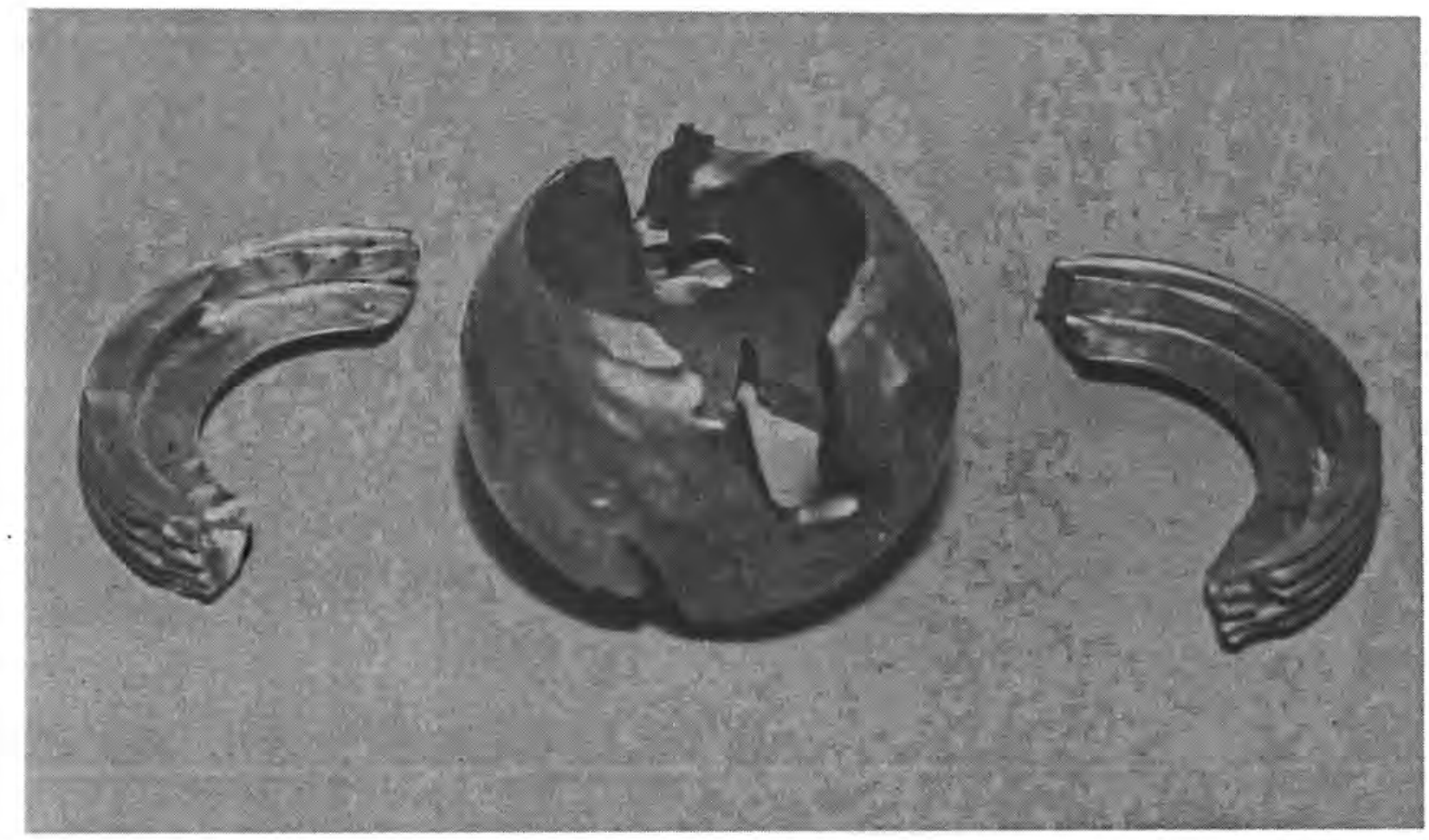

FIGURE 2. Eroded Ball and Retainer Collar from 2-in. Ball Valve Removed from Secondary Recirculation Loop

horizontal pipe sections of the primary recirculation loop. Over periods of 1 hour, sufficient accumulation could occur to cause plugging. Significant abrasion and erosion probably would occur with longer operating times using frit in the feed.

The vertical-cantilevered centrifugal pump feed system was used for almost four years, delivering $~ 390,000 \mathrm{~L}$ of various slurries in support of the full-scale spray calciner development. The system worked well for transferring feed compositions not containing abrasive solids. At the fluid velocities used, the solids caused excessive pipe and equipment wear. There are a number of improvements recommended to upgrade this type of system: 


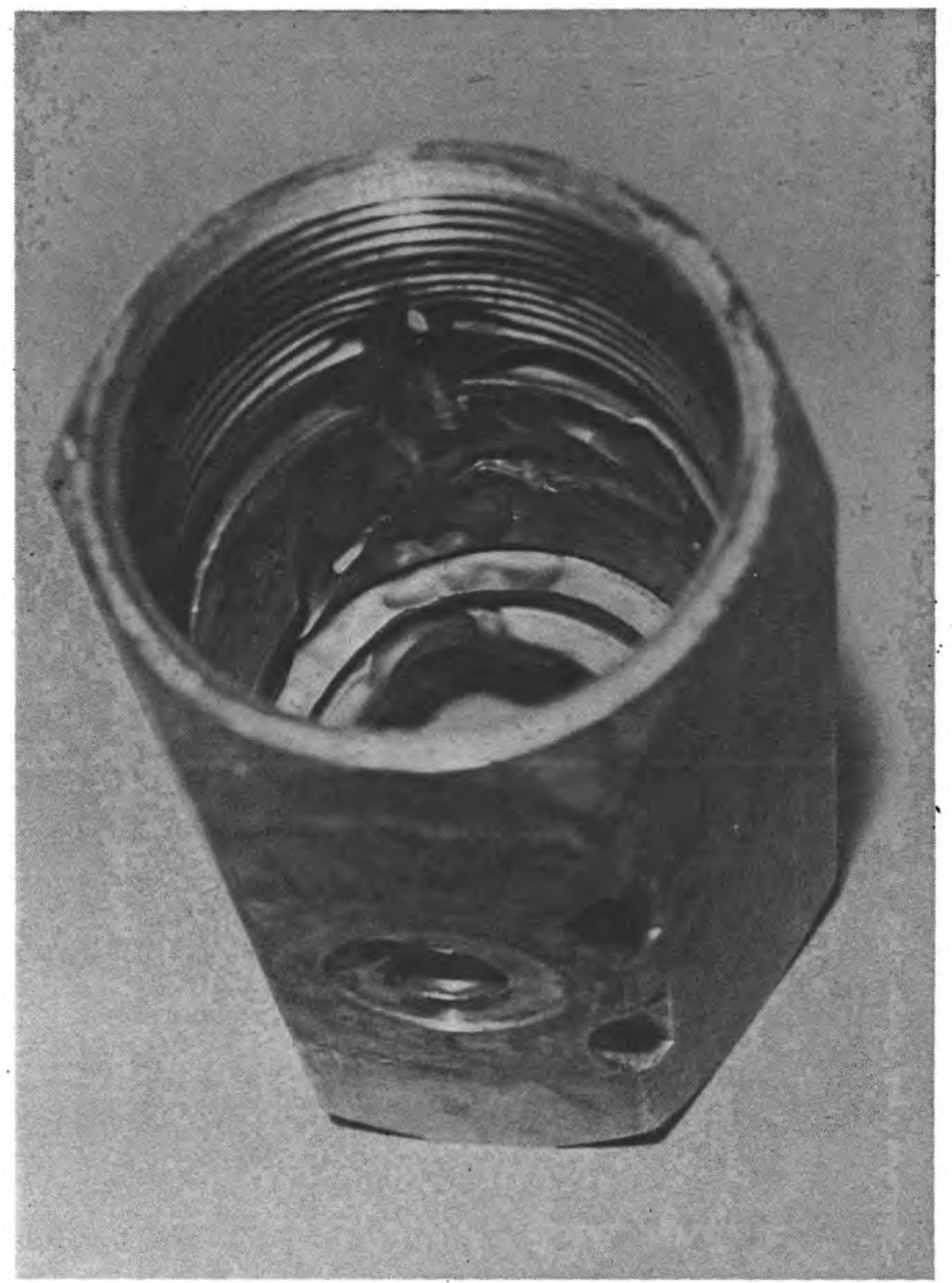

FIGURE 3. Eroded 2-in. Ball Valve Removed from Secondary Recirculation Loop 


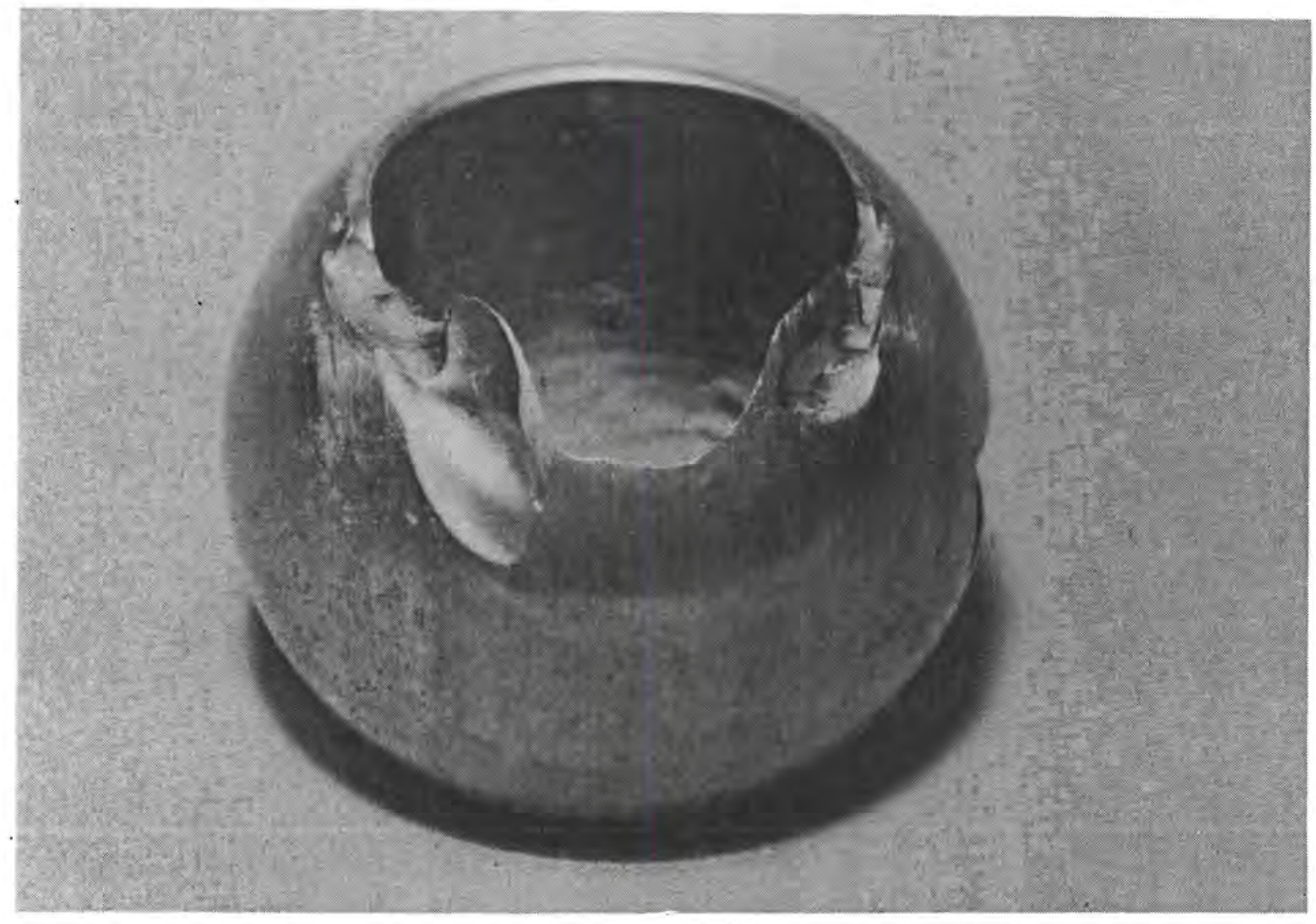

FIGURE 4. Eroded Ball from 1-in. Ball Valve Removed from Primary Recirculation Loop

- Pipe and equipment construction materials can be chosen with greater hardness values, thus decreasing wear significantly (see Appendix B for a discussion on choosing the proper materials).

- The PNL system admittedly was oversized in its recirculation flow rates. This necessitated using ball valves and a secondary recirculation 10op, which were both sites of excessive wear. Once feed composition and operational parameters such as flow rates have been specified, it will be possible to size a specific system. The secondary recirculation loop and the ball valves used to throttle the flow rates could then be el iminated. 
- The location of the feed storage tank and the melter equipment necessitated use of several hundred feet of horizontal piping. If a feed with rapidly settling solids is chosen, long horizontal sections of pipe could plug. Using a smaller-diameter piping for horizontal runs to maintain higher fluid velocities could help to prevent this.

- Many of the feed blockages encountered were from oversized particles finding their way into the feed system and then lodging in lines downstream. These included: a) feed or frit components that did not meet specifications; and b) dried lumps of feed that formed on feed tank walls, broke free and then entered the feed system. Strict specifications on feed preparation and materials alleviates these problems. Tank and in-line screens and strainers will remove any oversized particles entering the system.

\section{AIRLIFT FEED SYSTEMS}

Liquids transfer using airlifts is accomplished by injecting air into a liquid supply line near its lowest point. The combination of volume displacement and lowering of the effective fluid (air plus liquid) density in the lift line, relative to the liquid in the supply line, causes liquid flow to occur from the lower to the higher elevation in the lift line. The maximum height attainable is proportional to the ratios of the respective densities of the liquid and liquid-air mixture. It can be seen, then, that the air supply is one parameter which determines the maximum height attainable. Dabolt and Plummer (1980) advise air velocities of 0.9 to $1.2 \mathrm{~m} / \mathrm{s}(3$ to $4 \mathrm{ft} / \mathrm{s}$ ) for maximum efficiency. The other major parameter influencing lift height is submergence. Submergence is normally expressed as a percentage of the total lift-line length. As shown in Figure 5, the lift-line length is the distance from the air inlet point (footpiece) to the head pot. Submergence, then, is the ratio of "L" over "H". Most airlifts are designed to have a ratio of between 0.35 and 0.70 . Other parameters affecting airlifts are pipe diameter and fluid temperature. 


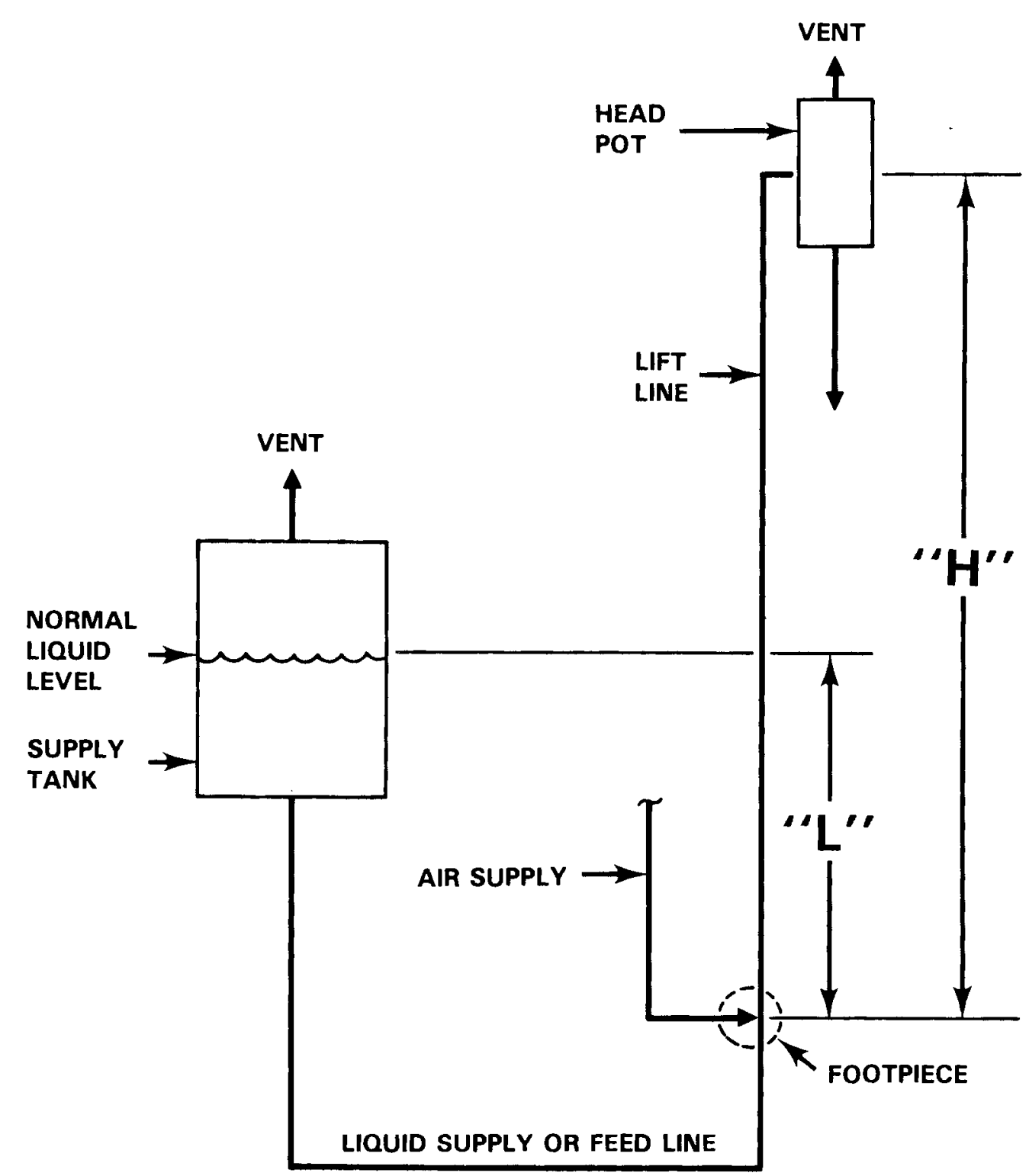

FIGURE 5. Typical Airlift Configuration (from Dabolt and Plummer 1980)

Two separate airlift systems have been used at PNL. The first system (shown in Figure 6) was previously used for acidic slurries from simulated power reactor wastes. Feed from a holding tank was pumped at a rate of $\sim 300 \mathrm{~L} / \mathrm{h}$ to a head pot $\sim 7.6 \mathrm{~m}(25 \mathrm{ft})$ above the holding tank. Overflow from the head pot returned to the holding tank. The slurry gravity flowed from the head pot down into the bottom of the airlift line at a rate of $\sim 200 \mathrm{~L} / \mathrm{h}$. The air/liquid mixture rose up into a disengaging pot where the air disengaged from the liquid. The feed slurry was then gravity-fed into the melter. 


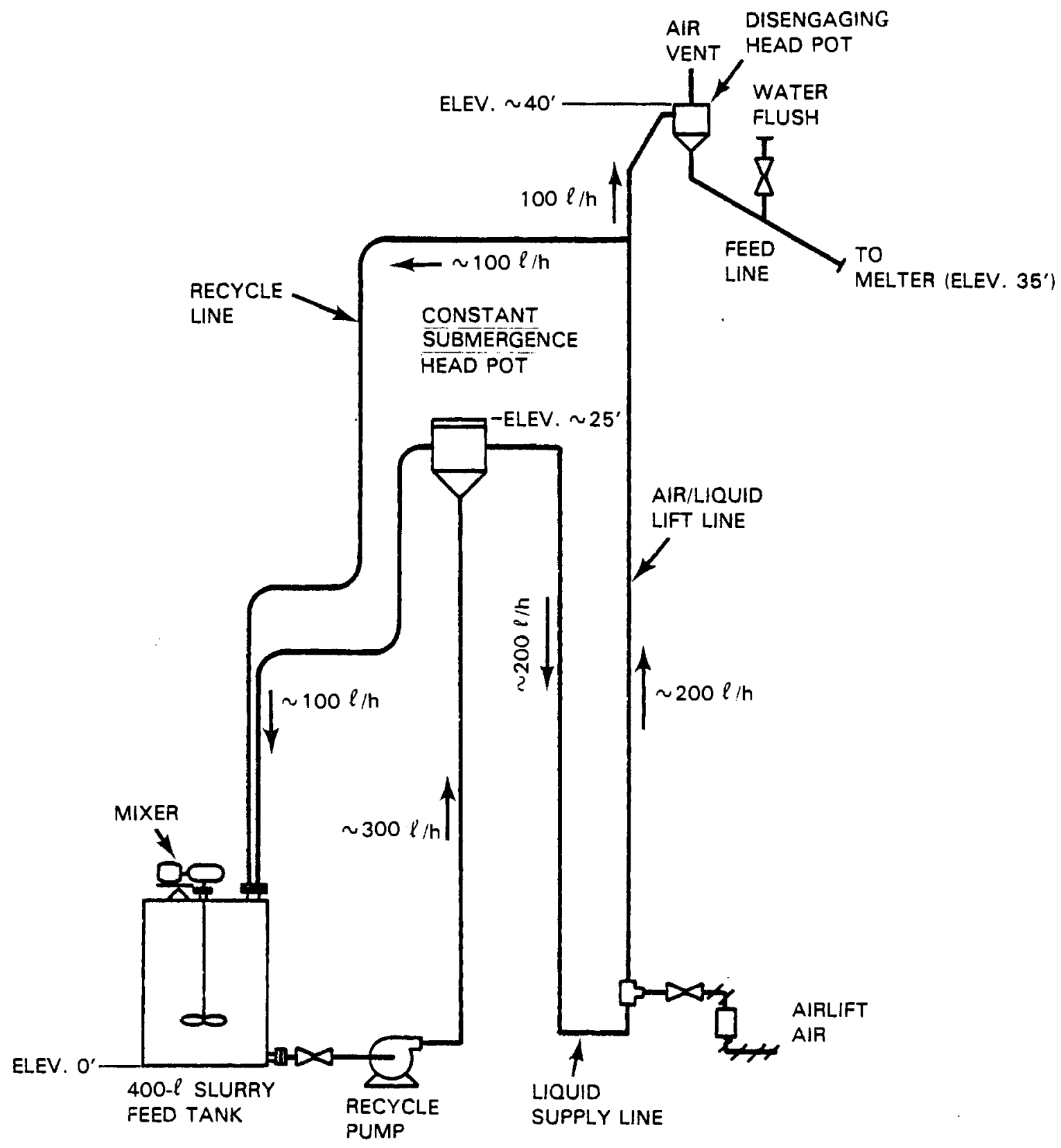

FIGURE 6. Feed System with Airlift Feed Metering 
This airlift-metering system was utilized to feed the Liquid-Fed Ceramic Melter (LFCM). Three separate runs (totaling 180 hours of operating time) were made. The longest run (LFCM-2) was 120 hours in length. The feed composition for these runs was simulated TDS waste sludge and Frit-211 (shown in Table 4). Solids loading for the three runs ranged from 320 to 522 g-oxide/L.

While the airlift effectively metered feed into the melter, problems arose with the piping system. Relatively low flow rates from the head pot to the airlift line were not sufficient to maintain the solids in suspension; consequently, plugging occurred. Plugging in the horizontal sections of the overflow line occurred for the same reason. Three modifications in the system are suggested:

1) Reducing the pipe diameter of these lines to increase the linear velocity of the slurry. This would have the two-fold benefit of increasing turbulence (and mixing) and reducing the residence time of the feed in these sections.

TABLE 4. Composition of Simulated TDS Waste Sludge and Frit-211

\begin{tabular}{lc}
\multicolumn{1}{c}{ Component } & Wt $\%$ \\
\cline { 2 - 2 } $\mathrm{Frit-211}$ & 66.7 to 69.2 \\
$\mathrm{Fe}(\mathrm{OH})_{3}$ & 17.4 \\
$\mathrm{Al}(\mathrm{OH})_{3}$ & 4.4 \\
$\mathrm{MnO}_{2}$ & 3.5 \\
$\mathrm{NiO}_{3} \mathrm{H}_{2} \mathrm{O}$ & 1.9 \\
$\mathrm{CaCO}_{3}$ & 1.6 \\
$\mathrm{NaNO}_{3}$ & 0.7 \\
$\mathrm{Na}_{2} \mathrm{SO}_{4}$ & 0.4 \\
Zeolite & 2.6 \\
Cornstarch $\left(\mathrm{C}_{6} \mathrm{H}_{10} \mathrm{O}_{5}\right)$ & 0.2 \\
Anthracite Coal & 0.7
\end{tabular}


2) Increasing the volumetric flow rate of the feed through these sections, which provides the same beneficial effects as reducing the pipe diameter.

3) Minimizing the horizontal sections of pipe to decrease areas of possible plugging.

The second airlift system, the Pilot-Scale Ceramic Melter (PSCM) slurry airlift system, was designed for transporting the feed entirely by airlift. This system, shown in Figure 7 , had the advantage that no mechanical devices (e.g., pumps, agitators and control valves) were required for feed transfer or tank agitation. All low spots, as well as the feed holding tank, were agitated with air to prevent solids accumulation. The location of the feed holding tank necessitated that a four-stage airlift be designed to raise the feed the required $10.7 \mathrm{~m}(35 \mathrm{ft})$ to the melter.

An air/slurry mixture can lift, effectively, about three times the height of the slurry head entering the airlift column. The feed slurry in the feed tank was lifted in this manner to head pot No. 1 (see Figure 8). At the bottom of the airlift column, a small amount of air was bubbled into the column to prevent solids from settling out in the footpiece. The airlift air was introduced into the lift 1 ine 15 to $25 \mathrm{~cm}$ (6 to $10 \mathrm{in}$.) higher on the airlift column. This location ensures that the air will rise up the airlift column rather than bubbling back into the liquid supply line.

Upon entering head pot No. 1, the air would separate from the slurry and be vented through the recirculation/overflow line. Then the feed slurry from head pot No. 1 was lifted in a similar manner to head pot No. 2, where sufficient head was developed to lift the slurry to head pot No. 3, located above the melter. To provide more accurate metering capabilities, a small airlift was installed in head pot No. 3. Airlift No. 4 (the metering airlift) was a concentric, $0.64-\mathrm{cm}(0.25-\mathrm{in}$.) tube inside a piece of $1.91-\mathrm{cm}(0.75-\mathrm{in})$. tubing. The feed flow to the melter was varied by changing the flow rate of the airlift air. The average feed rate was determined by the feed tank dropout. 


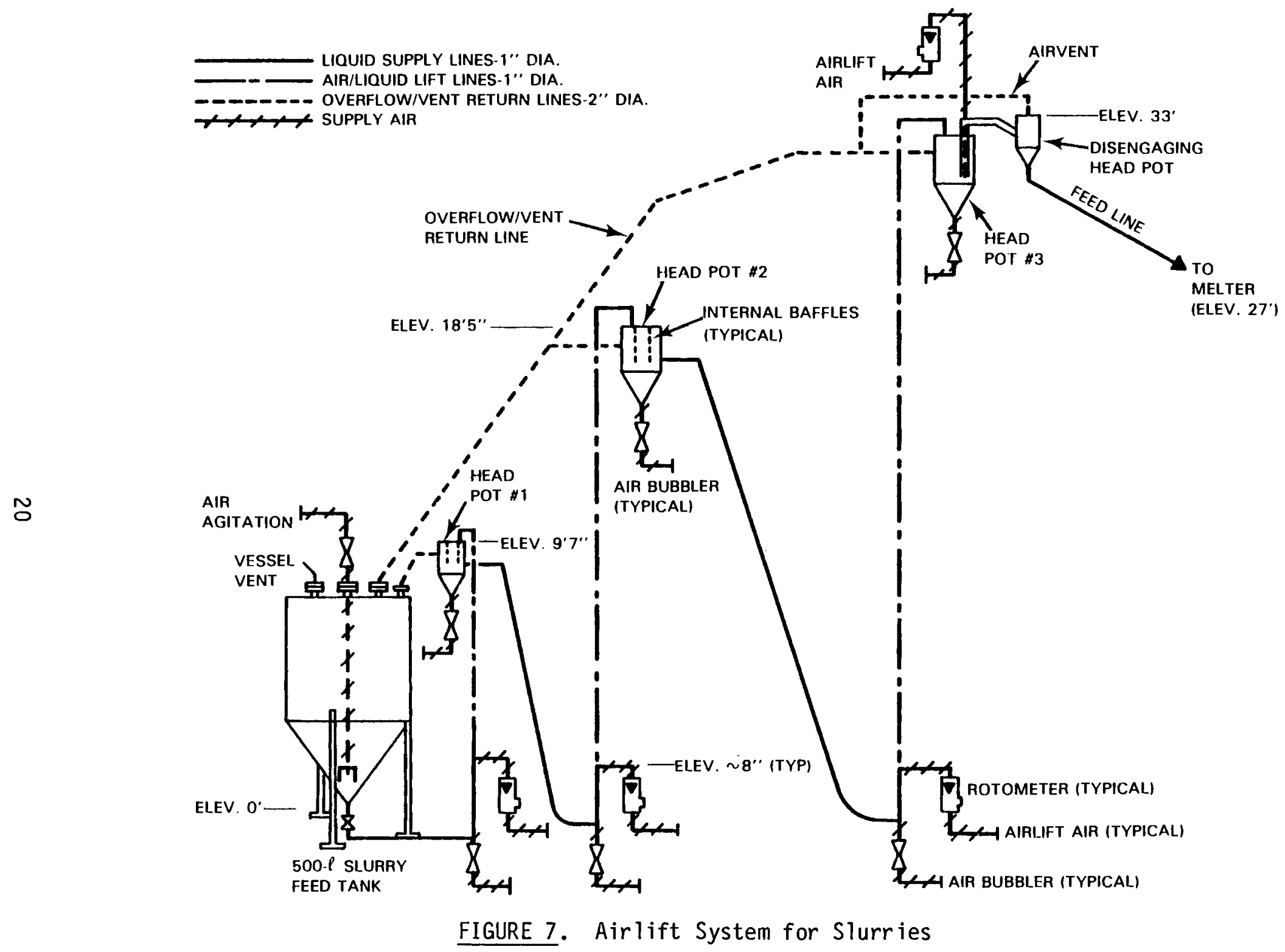




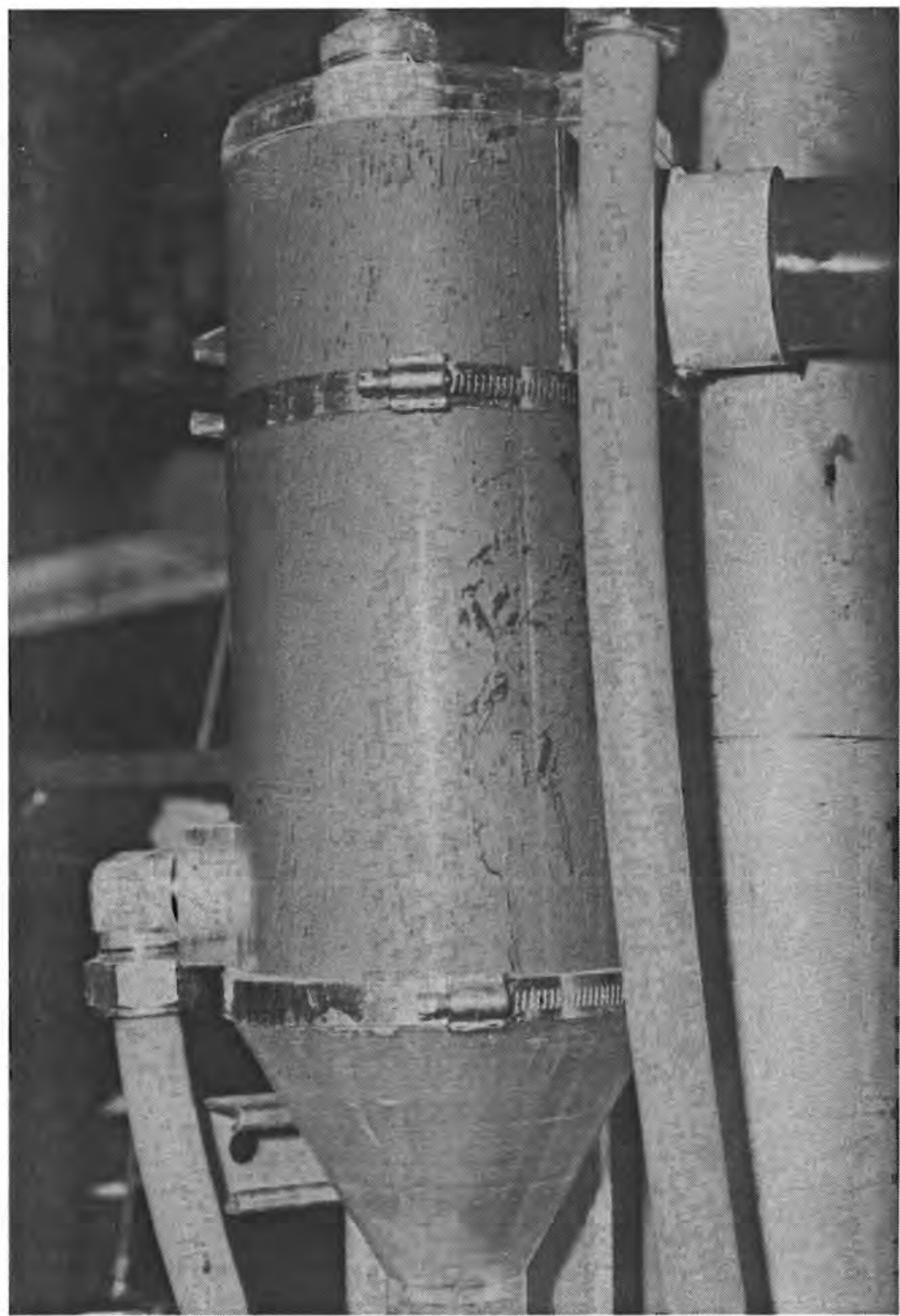

FIGURE 8. Plexiglass Head Pot--PSCM Airlift System

Prior to the first application of the airlift in a scheduled milestone run (PSCM-1), a 3-day test was successfully completed using a $\mathrm{MnO}_{2} / \mathrm{NiO} \cdot \mathrm{H}_{2} \mathrm{O} /$ frit slurry. This slurry contained 4 times the flowsheet value of $\mathrm{MnO}_{2}$ and 2.9 times the flowsheet value of $\mathrm{NiO} \cdot \mathrm{H}_{2} \mathrm{O}$. This provided a severe test of the system's ability to maintain solids in suspension.

Approximately $4660 \mathrm{~L}$ of simulated TDS waste sludge and Frit-131 was fed to the melter via the airlift system during a 169-hour test. Table 5 shows 
TABLE 5. Composition of Simulated TDS

Waste Sludge and Frit-131

\begin{tabular}{lr}
\multicolumn{1}{c}{ Component } & Wt\% \\
\cline { 1 - 1 } Frit-131 & 64.7 \\
$\mathrm{Fe}(\mathrm{OH})_{3}$ & 17.4 \\
$\mathrm{Al}(\mathrm{OH})_{3}$ & 4.0 \\
$\mathrm{MnO}_{2}$ & 3.7 \\
$\mathrm{NiO}_{2}-\mathrm{H}_{2} \mathrm{O}$ & 2.4 \\
$\mathrm{CaCO}_{3}$ & 1.7 \\
$\mathrm{NaNO}_{3}$ & 0.4 \\
$\mathrm{Na}_{2} \mathrm{SO}_{4}$ & 0.2 \\
$\mathrm{NaOH}$ & 1.0 \\
$\mathrm{SiO}_{2}$ & 1.1 \\
Zeolite & 2.8 \\
Anthracite Coal & 0.6
\end{tabular}

the composition of the slurry. The air/liquid lift lines of the airlift system functioned well. The gravity-drain feed line to the melter and the recirculation/overflow return lines from the head pots to the feed holding tank were susceptible to feed caking problems. The concentrated feed slurry used ( $480 \mathrm{~g}$-oxide/L) dried in the gravity drain lines at air/liquid interfaces in lines partially full of feed slurry. Periodically, the feed would coat the entire surface of these drain lines and then partially dry. This cyclic wetting and drying of the gravity drain lines caused a gradual buildup of a solid coating that eventually restricted the flow of the feed. Figures 9 through 11 show the extent of the problems encountered. Hourly water flushes of $\sim 1 L$ through these lines helped minimize solids buildup and allowed continued operation of the system for the duration of PSCM-1. This volume of water did not significantly burden the melter with additional drying requirements or dilute the feed.

No further testing of the PSCM a irlift system took place because there was an immediate need for a reliable system to support melter studies. Due to 


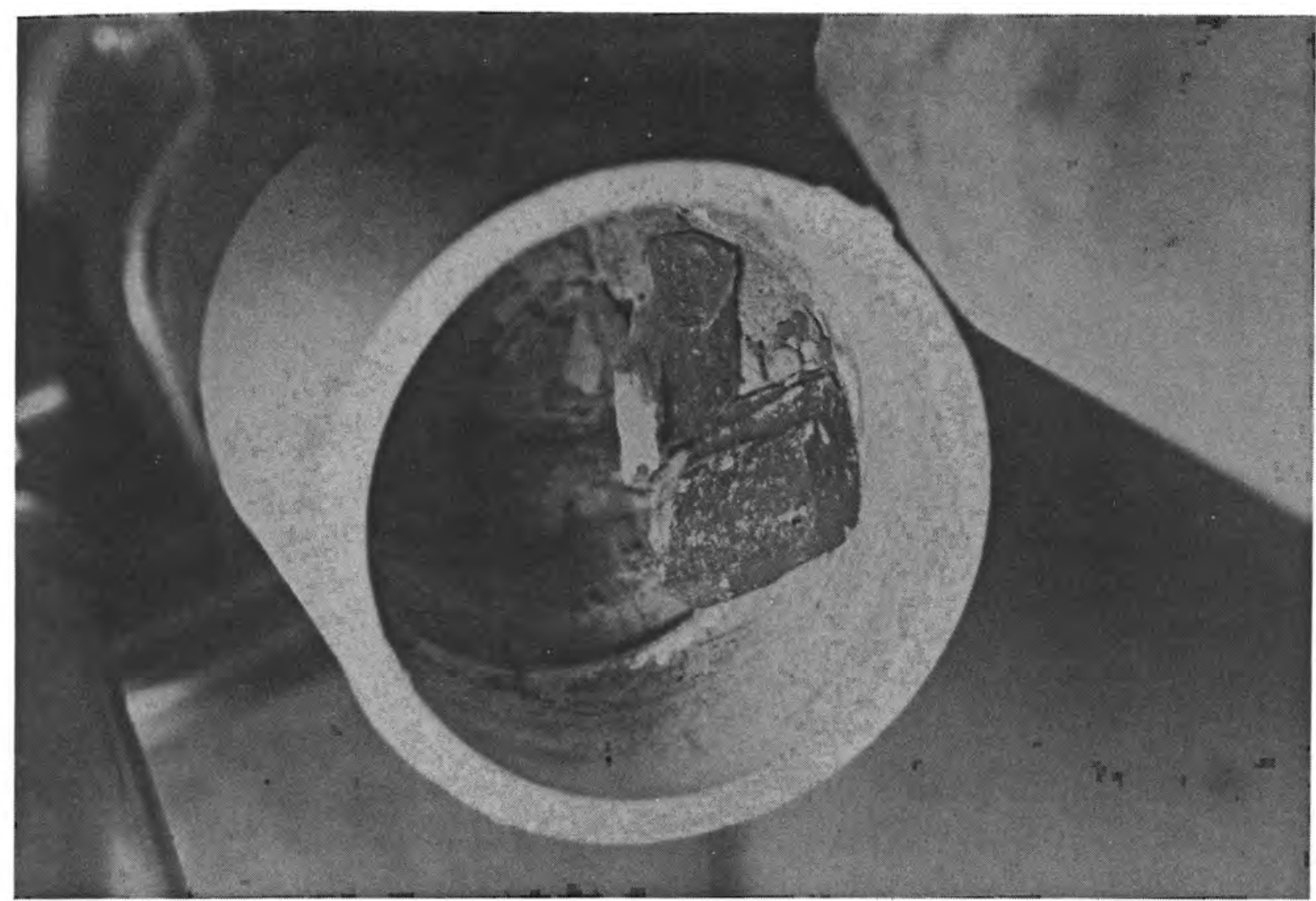

FIGURE 9. Dried Solids Accumulation Inside a Recirculation/Overflow Return Line 


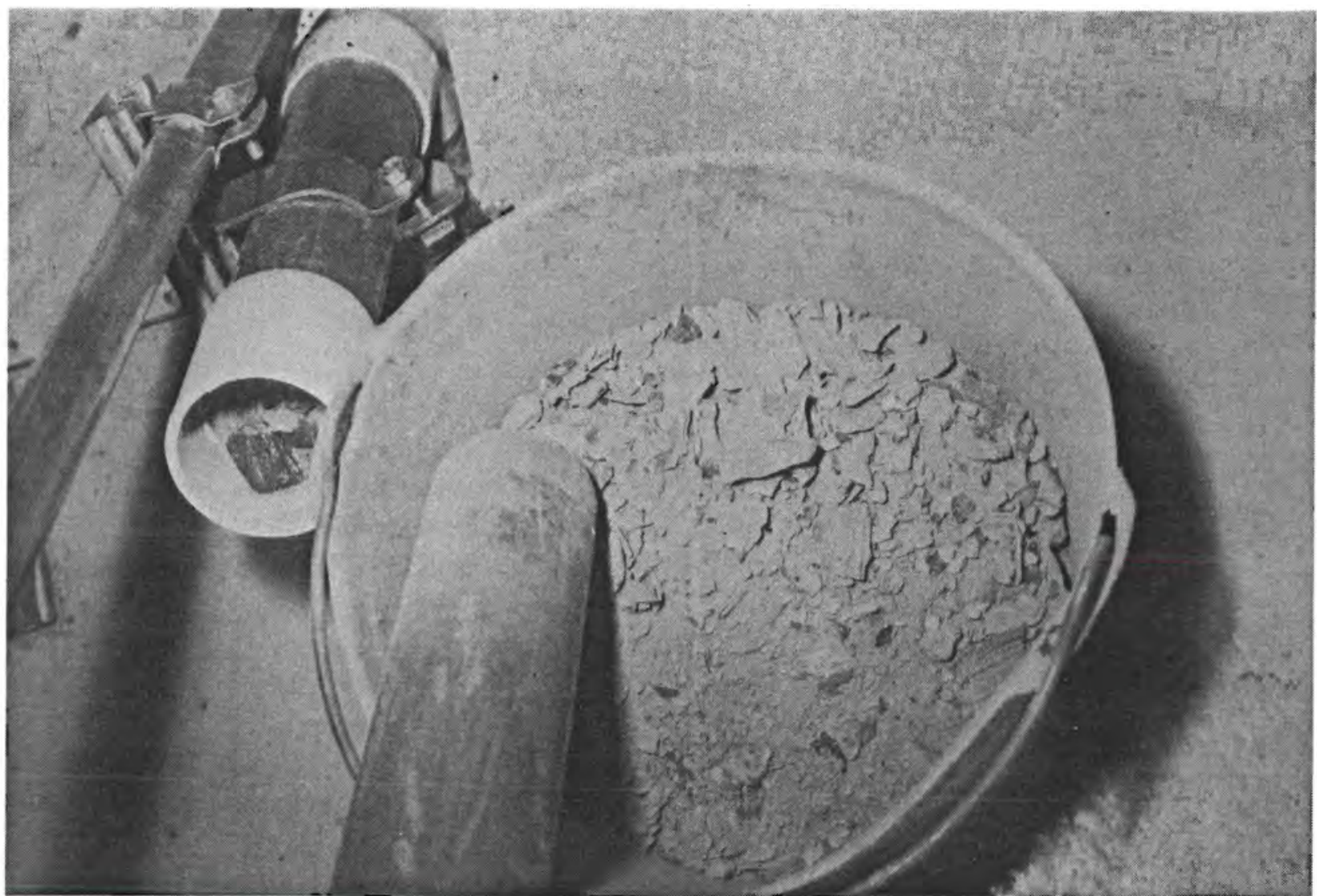

FIGURE 10. Dried Solids Collected from Recirculation/Overflow Return Lines 


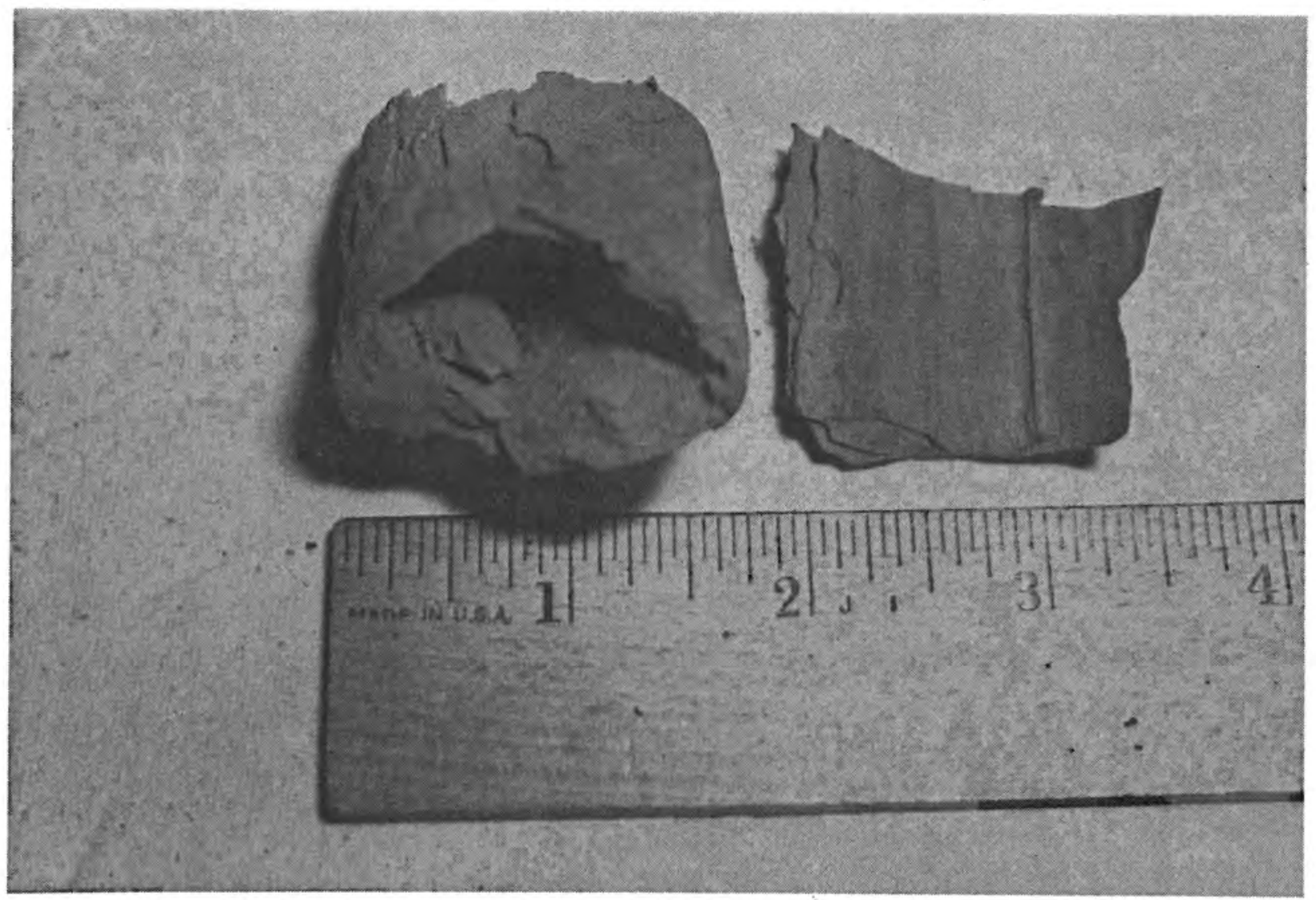

FIGURE 11. Samples of Solids Collected from Recirculation/Overflow Return Line 
the more complicated nature of the four-stage system, modifications to rectify the plugging problems could not be designed before other scheduled melter milestone runs. Also, the loss of technical personnel directly involved with development of the airlift made further testing impractical.

The plugging problems experienced by the airlift system in the recirculation/overflow return lines can be traced to one main factor, the drying effect the vented air had on the feed. Four suggested modifications to the design of the airlift are:

1) Redesign the head pots to provide separate vents for the recycling feed slurry and the air.

2) Use humidified air or inert gas to minimize the drying effects of the air.

3) Reduce the pipe diameter of the recirculation/overflow return lines to reduce the contact surface area available for drying.

4) Increase the volumetric flow rates to the head pots to ensure that feed is regularly flowing through the recirculation/overflow return lines. This would prevent the cyclic wetting and drying prevalent during PSCM-1.

\section{PRESSURIZED-LOOP SYSTEMS}

The positive displacement pump and recirculation-loop system operated along the same principle as the earlier vertical-cantilevered centrifugal pump. Feed was recycled from a feed holding tank through a recirculation loop. The amount of feed entering the feed line at the top of the loop was determined by the pressure in the recirculation loop. A range of pressures was possible by adjusting valves in the recirculation loop.

The first pressurized loop utilized a variable-speed, peristaltic pump in the feed line to meter the amount of feed entering the melter (see Figure 12). The feed rate was measured by a mass flowmeter. (a) A pneumatic diaphragm pump $^{(b)}$ was used to recirculate feed through the loop. A mechanical agitator

(a) Micro-Motion Model B-25.

(b) Warren Rupp Co., Model ST 1-1/2A Sandpiper. 


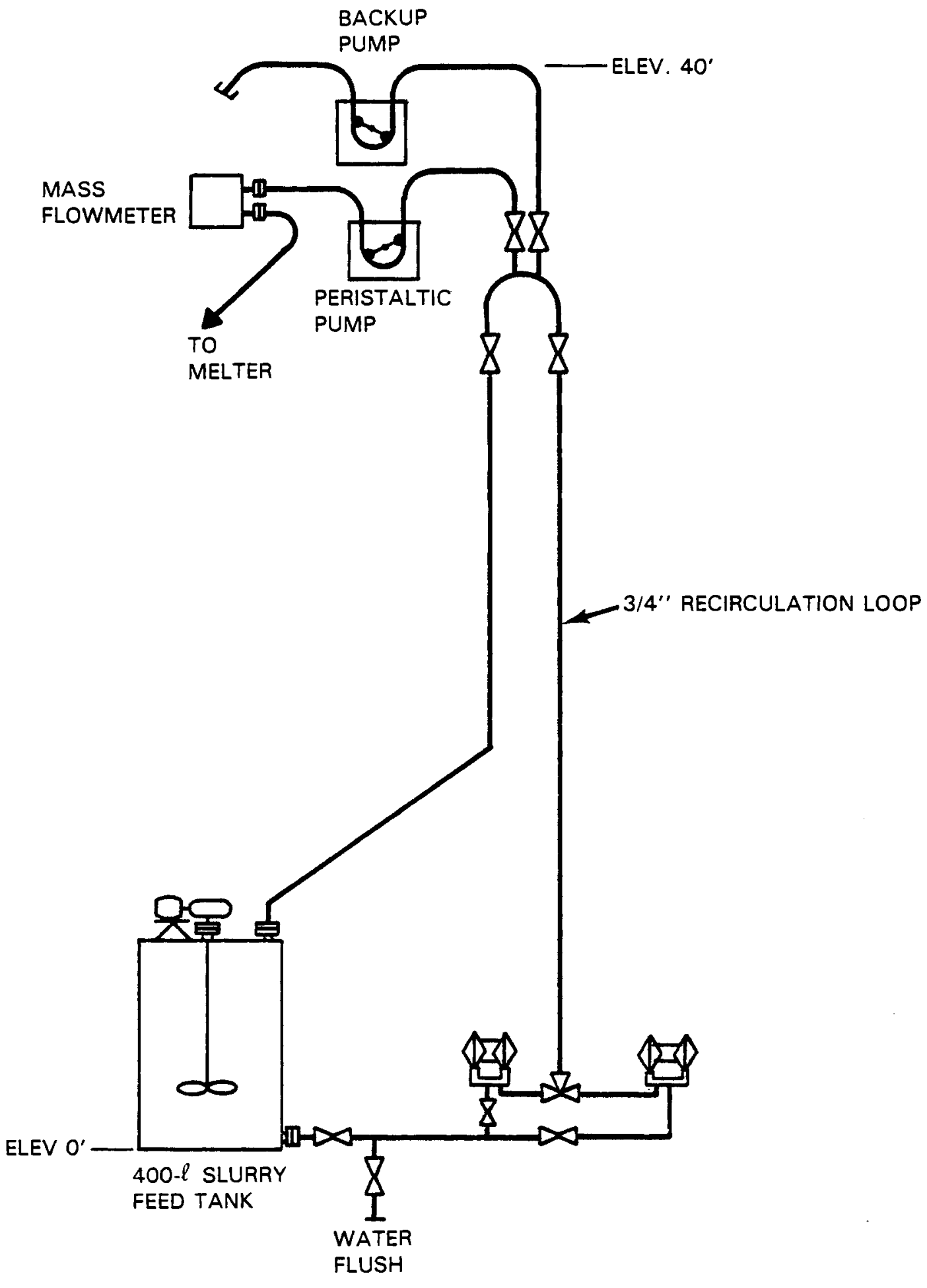

FIGURE 12. Positive-Disp lacement Pump-Loop System with Metering System 
was used to keep the solids in suspension in the feed holding tank. Two different variable-speed peristaltic pumps were tested to control melter feed rates. (a) Both of these pumps are of the flexible-tubing type with rollers that compress the tubing and move the feed forward. The flexible tubing required replacement every 15 to 24 hours due to cuts resulting from the pump rollers compressing the abrasive feed solids against the tubing. While both pumps performed adequately, the Model 610 pump developed higher feed pressures and was therefore able to move solids through the flowmeter with less plugging. Both peristaltic pumps were affected by fluctuating recirculation line pressures caused by the changing feed tank liquid level. This caused the feed rate to drift while the pumps maintained constant roller rpms.

This feed system was used during a test lasting 134 hours (LFCM-6). The feed composition was the same as the PSCM-1 run (Table 5). Feed blockages in the diaphragm recirculating pump occurred in the diaphragm chambers. The pump is designed so feed enters and exits the diaphragm chamber at the midpoint of the pump chamber's side. This created a "dead zone" at the bottom of the chamber where feed solids settled. Feed blockages also occurred in the mass flowmeter. The feed blockages in the flowmeter and the diaphragm pump were due, in large part, to feed particles with diameters $>0.61 \mathrm{~cm}(0.24 \mathrm{in}$.) (the orifice diameter of the flowmeter). The origin of these particles was fragments of dried feed from the feed holding tank and feed that did not conform to specifications. Strainers with openings $<0.61 \mathrm{~cm}$ in diameter eliminated further feed blockages in the flowmeter.

While this system was able to deliver a solids-laden slurry to the melters, fluctuating feed rates and the need to frequently replace the pump tubing resulted in this system being modified to eliminate the peristaltic pumps. This revamped feed system operated on the principle of controlling the feed rate by controlling the line pressure in the recirculation loop. Figure 13 shows the feed system network and associated instrumentation. After exiting the holding tank (TK-5), feed passed through one of two redundant strainers which filtered out any particles or lumps larger than $0.40 \mathrm{~cm}$ (0.16 in.). The feed was then pumped by a pneumatic diaphragm pump into the

(a) Monostat Varistaltic (advanced model) and a Randolph Model 610. 


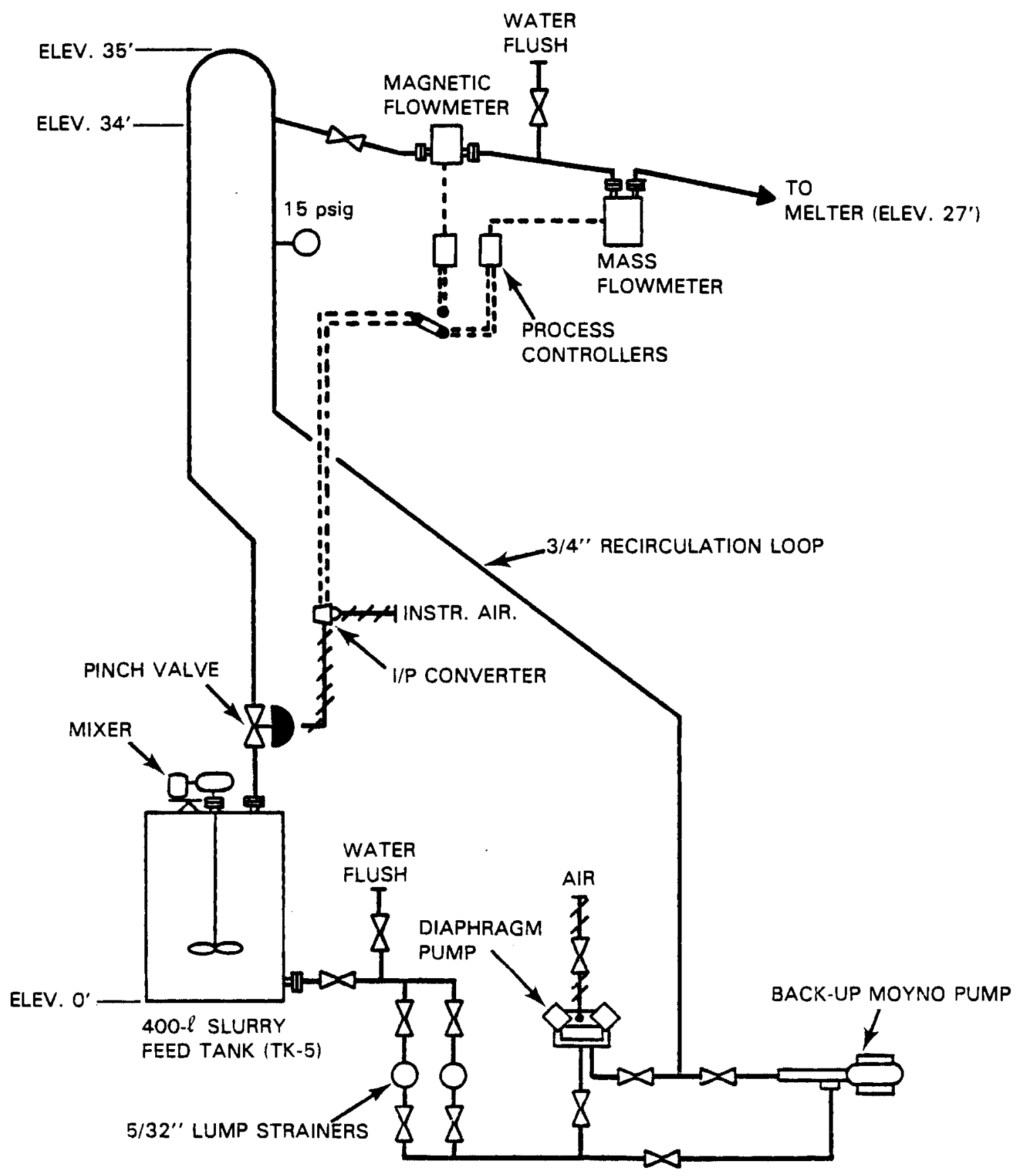

FIGURE 13. Positive-Displacement Pump-Loop System Utilizing Air-Operated "Pinch" Valve 
recirculation line. This line was fabricated of 1.9-cm (0.75-in.) dia, 0.09-cm (0.035-in.) thick wall, stainless steel tubing. The Moyno progressive-cavity pump, (a) shown in the network, served as a backup replacement pump.

From the pump discharge, the feed moved through a sloping, $45^{\circ}$ vertical line to a height of $10.7 \mathrm{~m}(35 \mathrm{ft})$. At the $10.4-\mathrm{m}(34-\mathrm{ft})$ elevation point, the feed line was attached. Of the feed slurry, 90 to $95 \%$ continued through the recirculation line and returned to TK-5. Slurry that entered the feed line passed through a magnetic volumetric flowmeter $(b)$ and then through a mass flowmeter. The output of either of these sensors could be utilized as feedback by an automatic process controller regulating the pressure drop across the recirculation loop "pinch" valve ${ }^{(c)}$ located near the end of the recirculation loop. After exiting the mass flowmeter, the feed gravity flowed about $4.0 \mathrm{~m}(13 \mathrm{ft})$ down to the water-jacketed feed nozzle and into the melter. Except for a few feet of $1.3-\mathrm{cm}(0.5-\mathrm{in}$.$) polyethylene tubing on$ either side of the mass flowmeter, the entire feed line was fabricated from 1.3-cm (0.5-in.) dia, 0.09-cm (0.035-in.) thick wall, stainless steel tubing. The flowmeter was isolated from the stainless steel tubing in order to eliminate the effects of building vibrations on the instrument.

Flow rates through the recirculation line were maintained at $-20 \mathrm{~L} / \mathrm{min}$, giving a fluid velocity of $\sim 1.4 \mathrm{~m} / \mathrm{s}(4.7 \mathrm{ft} / \mathrm{s})$. This high flow rate assured that turbulent conditions would exist throughout the line, keeping the suspended particles from settling out. The linear velocity in the feed line, based on a feed rate of $40 \mathrm{~L} / \mathrm{h}$, was $0.12 \mathrm{~m} / \mathrm{s}(0.4 \mathrm{ft} / \mathrm{s})$. Although this was a rather low velocity, $-85 \%$ of the feed line was downward sloping. Also, at $0.4 \mathrm{ft} / \mathrm{s}$, the residence time of the slurry through the feed line was -1 minute. This was too short a time to expect appreciable settling. At times, 50 to $100 \mathrm{ft}$ of $3 / 8-i n$. plastic tubing was added just upstream of the mass flowmeter to increase the pressure drop in the feed line. No plugging ever occurred in this line.
(a) Robbins and Myers Moyno pump.
(b) Fisher and Porter Model 10D1418A.
(c) Flexible Valve Corp. Model 6301. 
This system performed very well during five experiments, PSCM-3, 4, 5, 8 and LFCM-7, covering 618 hours during which $>42,000 \mathrm{~L}$ of a formic acid feed slurry was fed to the glass melters. Table 6 gives the composition of the formic acid feed. During four of the five experiments no feeding stoppages occurred from plugging or feed-system failure. The only experiment with feeding problems, LFCM-7, was the second experiment to use this system. Throughout the 111-hour test 25 short feeding interruptions occurred and resulted in 8.5 hours of downtime. A11 of these stoppages were caused by solids accumulation in the diaphragms of the recirculation pump.

During a post-run examination of the pump, a number of factors were identified that might have caused the pumps to falter after working flawlessly during PSCM-3. First, to maintain the 100 to $150 \mathrm{~L} / \mathrm{h}$ of feed to the melter, the pinch valve was operating at 90 to $95 \%$ closure. This put more resistance pressure on the pump to maintain a constant head. Second, the Rupp pump is constructed with two diaphragms in each chamber: the piston diaphragm is bolted to the air piston, while the process diaphragm contacts the process fluid. Water is placed between the diaphragms to transfer energy from the piston diaphragm to the process diaphragm. The water level was well below its prescribed level during the LFCM-7 run, causing severe deformation of the process diaphragm, which is made of Tefion. The Tefion ball checks also were badiy worn. A number of modifications were made to correct these errors and improve the general efficiency of the pump. The process diaphragms and ball checks were replaced. The slurry inlet/outlet port was relocated from the midpoint to the bottom of the chambers to minimize the possibility of solids accumulating. The inlet line from the feed tank to the pump was enlarged from 1.9-cm (3/4-in.) -dia to 2.5-cm (1-in.) -dia pipe. The Rupp pump manufacturer strongly suggests that for maximum efficiency this line be no smaller than the pump inlet/outlet port diameter. Finaliy, since the feed slurry passed through strainers $p l a c e d$ in the transfer lines between the feed make-up tanks and the feed tank, and the formic acid feed did not form lumps in the feed tank as previous alkaline slurries had; the lump strainers in the pump inlet line were deemed unnecessary and removed. With these modifications completed,

E. I. du Pont de Nemours \& Company, Inc. 
TABLE 6. Composition of Simulated TDS Formic Acid Waste and Frit-131

\begin{tabular}{|c|c|c|}
\hline \multicolumn{3}{|c|}{ Waste Slurry $(2090 \mathrm{~L})(\mathrm{a})$} \\
\hline Compound & $\mathrm{wt}, \mathrm{kg}$ & $\begin{array}{l}\text { Concentra- } \\
\text { tion, } g / L\end{array}$ \\
\hline Frit-131 & $713.4^{(b)}$ & 341.3 \\
\hline Zeolite & $20.7^{(c)}$ & 9.9 \\
\hline $\mathrm{Fe}(\mathrm{OH})_{3}$ & 169.8 & 81.2 \\
\hline $\mathrm{Al}(\mathrm{OH})_{3}$ & 71.4 & 34.2 \\
\hline $\mathrm{Mn}\left(\mathrm{CHO}_{2}\right)_{2}$ & -- & 28.2 \\
\hline$\left(\mathrm{MnCO}_{3}\right)(\overline{\mathrm{d}})$ & $(46.7)$ & -- \\
\hline $\mathrm{Ni}\left(\mathrm{CHO}_{2}\right)_{2}$ & 17.3 & 8.3 \\
\hline $\mathrm{Ca}\left(\mathrm{CHO}_{2}\right)_{2}$ & 35.0 & 16.7 \\
\hline $\mathrm{SiO}_{2}$ & 32.6 & 15.6 \\
\hline $\mathrm{NaCHO}_{2}$ & 17.6 & 8.4 \\
\hline $\mathrm{NaNO}_{3}{ }^{2}$ & 4.2 & 2.01 \\
\hline $\mathrm{Na}_{2} \mathrm{SO}_{4}$ & 1.5 & 0.72 \\
\hline $\mathrm{HCHO}_{2}$ & 90.8 & $\mathrm{pH} 5.5$ to 7 \\
\hline Total & 1142.4 & 546.6 \\
\hline
\end{tabular}

(a) Feed slurry glass content $=0.478 \mathrm{~kg} / \mathrm{L}$.

(b) Frit-131 composition (-200 mesh)

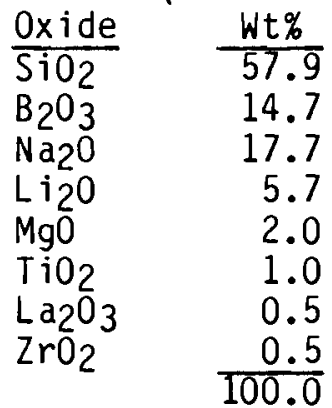

$\rightarrow$ (c) Zeolite composition (Linde Ionsiv IE-95)

$$
\begin{array}{ll}
\frac{\text { Component }}{\mathrm{CaAl} \mathrm{Si}_{4} \mathrm{O}_{12} \cdot 6 \mathrm{H}_{2} \mathrm{O}} & \frac{\mathrm{Wt} \%}{80} \\
\mathrm{Na}_{4} \mathrm{Ca}_{1.5^{\mathrm{Al}} \mathrm{S}_{3} \mathrm{Si}_{8} \mathrm{O}_{24} \cdot 8 \mathrm{H}_{2} \mathrm{O}} & \frac{20}{100}
\end{array}
$$

(d) Carbonate form of chemicals shown in ( ) were reacted with formic acid to form the required formates. 
the feed system performed well during the final three experiments. Figure 14 shows a plot of feed rate versus time for the PSCM-5 experiment, in which the feed rate was maintained to within $3 \%$ of the setpoint values.

As was mentioned earlier, the last five experiments were carried out with a formic acid slurry. The oxide loading of $\sim 480-g$-oxide/L slurry was the same as the previously used alkaline slurry. The feed composition for PSCM-8 differed only in that another frit composition, frit-165, was used (see Table 7). The difference did not have any effect on the feed rheology. The formic-acid feed had better pumping characteristics. This feed had a $\mathrm{pH}$ of 5.5 to 7.0 as compared to a pH of -11.5 for the alkaline slurry. Because of this, feed components such as ferric hydroxide, $\mathrm{Fe}(\mathrm{OH})_{3}$, were soluble to a much greater extent. Manganese, nickel, calcium and sodium were more water soluble as formates than as oxides, hydroxides or carbonates. In addition, coal, which had been difficult to keep in suspension in the past, was not a component of the formic acid slurry.

In conclusion, this pressurized recirculation loop system handled the formic acid feed well. Mechanical difficulties that arose were corrected. Inspection of the feed system showed no noticeable wear in either the valves or piping. The elastamer tube of the "pinch" valve also showed no noticeable wear.

\section{POSITIVE-DISPLACEMENT PUMP SYSTEM}

The fourth feeding system tested at PNL was a positive-displacement pump system that delivered feed slurry directly to the PSCM. This was the only system lacking a liquid recirculation line of some sort. The feed tank for this system was located just $5 \mathrm{ft}$ from the PSCM and a pump capable of operating at the low, required flow rate range of 45 to $100 \mathrm{~L} / \mathrm{h}$ was used. A schematic of the feed system and associated instrumentation is shown in Figure 15. The feed tank, TK-60, was an $850 \mathrm{~L}, 1.2-\mathrm{m}$ (4-ft) -dia, $60^{\circ}$ conical-bottom tank with a $\sim 15-\mathrm{cm}$ (6-in.) spherical-radius cone bottom. Agitation of the slurry was by a syringe-like pulse agitator. The agitator consisted of a 12.7-cm x 76.2-cm (5-in. $x$ 30-in.) driver and a 30.5-cm $x$ 


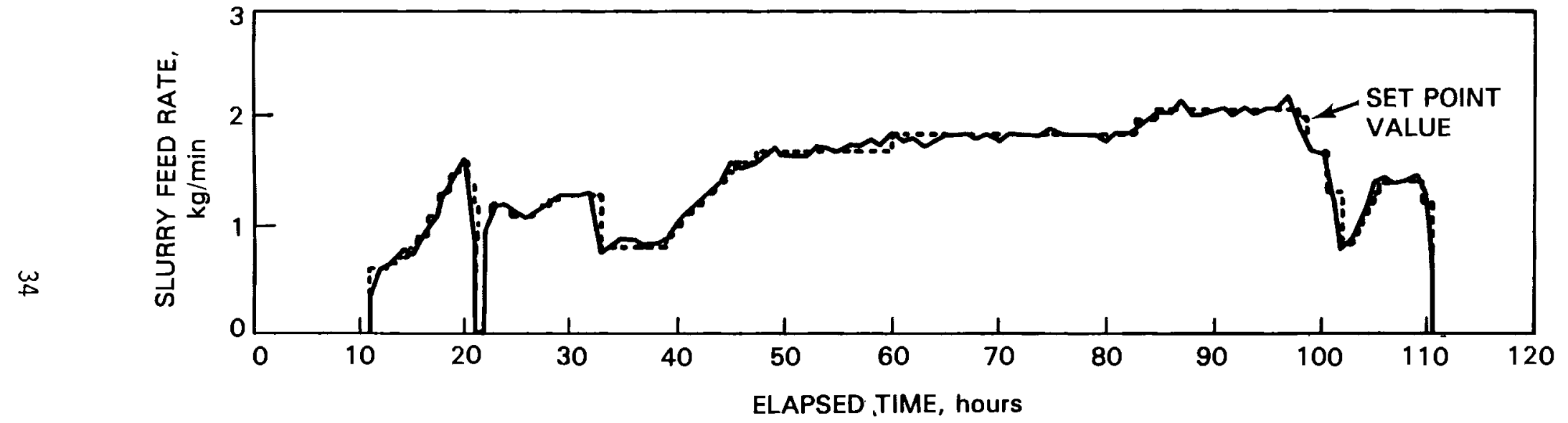

FIGURE 14. Feed Rate Versus Time: PSCM-5 
TABLE 7. Composition of Frit-165 (-200 mesh)

\begin{tabular}{lr}
$\frac{\mathrm{Oxide}}{\mathrm{SiO}_{2}}$ & $\mathrm{Wt} \%$ \\
\cline { 3 - 3 } $\mathrm{B}_{2} \mathrm{O}_{3}$ & 68.0 \\
$\mathrm{Na}_{2} \mathrm{O}$ & 10.0 \\
$\mathrm{Li}_{2} \mathrm{O}$ & 13.0 \\
$\mathrm{MgO}$ & 7.0 \\
$\mathrm{ZrO}_{2}$ & 1.0 \\
& 1.0 \\
& 100.0
\end{tabular}

76.2-cm (12-in. $\times 30-i n$.$) pulse generator. The agitator was operated on a$ $60-$ second cycle. During the 7-second suction stroke, $-55 \mathrm{~L}$ of slurry were drawn into the pulsator. Fifteen seconds later the slurry was driven out of the pulsator during the 3-second discharge stroke. The slurry exited the 5.1-cm (2-in.) ID pulsator tip at a velocity of $-3.1 \mathrm{~m} / \mathrm{s}(10 \mathrm{ft} / \mathrm{s})$ causing a 5.1-cm (2-in.) tank level change in the linear tank section. The slurry surface became motionless $\sim 7$ seconds after the discharge stroke started, but the turnover and agitation of the slurry was adequate.

The slurry was pumped from the feed tank by a variable speed ( 0 to $300 \mathrm{rpm})$, progressive-cavity pump (a) through a mass flowmeter and directly to the melter through the $0.95-\mathrm{cm}(0.38-i n$.$) feedline tubing. The pump was$ driven by a 0 - to $1700-r p m D C$ motor via a $6: 1$ gear reducer to keep the motor speed high for increased torque. Feedback signals from the flowmeter were used to control the motor speed and so maintain a constant feed rate. The pump shaft was connected to the gear-reducer shaft with a water-purged double mechanical seal. Figure 16 is a photograph of the installed system.

Following approximately two months of continuous operation, the pulse agitator was inspected. The piston rod seal on the $12.7-\mathrm{cm}\left(5-\mathrm{in}_{0}\right)$

drive-piston unit was the only maintenance required. No wear of the stainless steel pulsator nozzle was noted, and only minor shining of the feed tank bottom at the pulsator jet impact point was observed. Caked accumulations on the pulsator and tank walls were minimal.

(a) Robbins and Myers Moyno Model 3M2 55Q. 


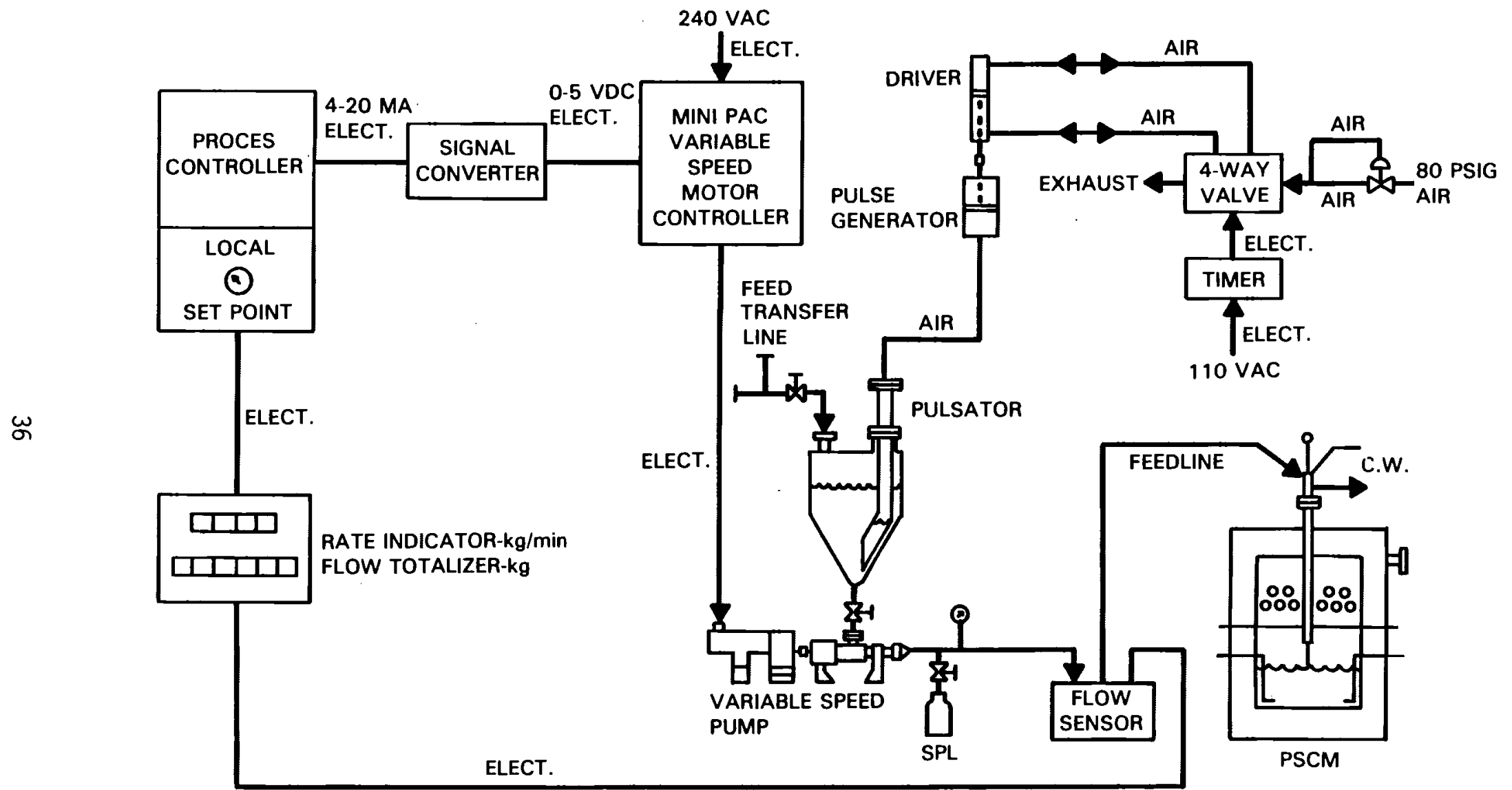

FIGURE 15. Positive-Displacement Pump System 


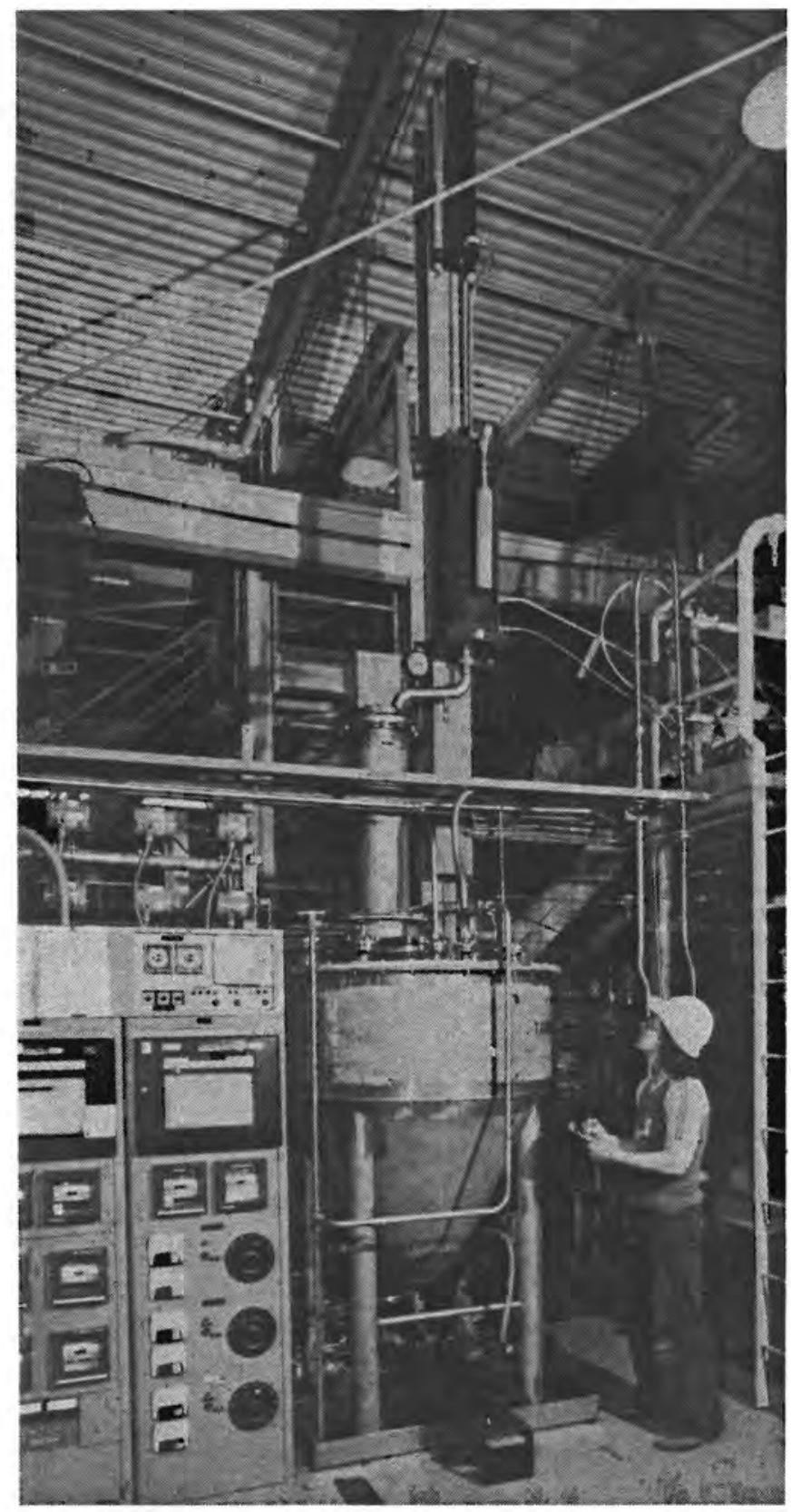

FIGURE 16. Installed Positive-Displacement Pump System 
The Moyno progressive-cavity pump also was disassembled for inspection, after having accumulated 500 hours of service time pumping the frit-laden, simulated waste slurries. No damage to the pump was apparent; the mechanical seals were not disassembled, but they showed no signs of leakage, either toward the process side of the seals or toward the outside of the pump housing. The suction side of the pump was solidly packed with coarse solids (frit lumps, ferric-hydroxide lumps, and miscellaneous non-slurry debris such as wire brush wires, bits of aluminum bottle caps or wood, etc.), although this apparently did not affect the flow of slurry feed to the pump stator. The pump cavity wall stator (Buna-N elastomer) showed some signs of abrasive wear where places in the original shiny surface had been dulled slightly. The 316 stainless steel pump rotor, which rotates within the stator, showed no damage, although it had been buffed to a very shiny surface. Minute inspection at the front 5.1 to $7.6 \mathrm{~cm}$ (2 to 3 in.) revealed some circumferential striations that suggested abrasive particles had become embedded in the stator for a short period and had scratched the rotor slightly. The universal joint seal showed the usual dulling of the elastomer surface, but no failure had occurred.

The PSCM-6 experiment accounted for 138 hours of the first 500 hours. Continuous operation was achieved, delivering $\sim 8650 \mathrm{~L}$ of slurry to the PSCM. No feed pluggages in the system occurred as the feed rate control system maintained a feed rate within $3 \%$ of the setpoint values. Figure 17 shows feed rate versus time for the entire experiment.

Following the 500-hour inspection, the system was used during three additional experiments: PSCM-7, 8 and 9 . During PSCM-7, 4250 L of a slurry concentrated to $\sim 50 \mathrm{wt} \%$ solids (containing 621 g-oxide/L slurry) was fed to the PSCM over a 115-hour period. Table 8 shows the composition of the slurry. The pump worked very well, but the flowmeter was prone to plugging at liquid rates $<1.0 \mathrm{~kg} / \mathrm{min}$. An after-the-fact examination of the sensor output showed that it had probably plugged 6 or 7 times during the experiment, while 3 or 4 times it was unplugged by normal pressure/velocity excursions precipitated by the controller action. Three of the plugs, however, did completely plug the flow sensor, stopping the flow of feed to the melter. These plugs could not be cleared by flushing the line and had to be physically 


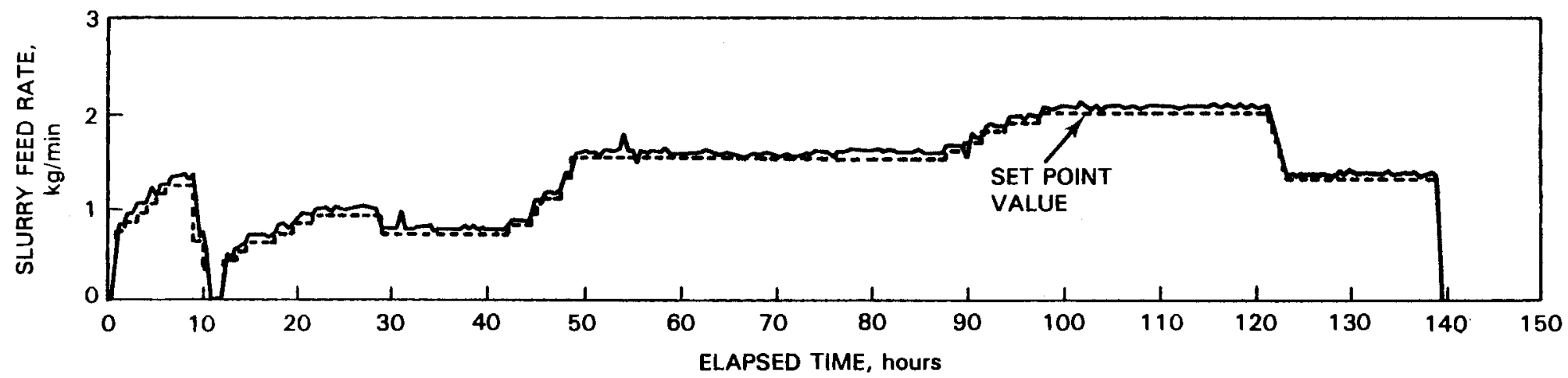

FIGURE 17. Feed Rate Versus Time: PSCM-6 Experiment 
TABLE 8. Composition of 50 wt\% Simulated TDS Formic Acid Waste and Frit-165

Waste Slurry (basis: 1000-L batch)

\begin{tabular}{|c|c|c|}
\hline Compound & Weight, $\mathrm{kg}^{(\mathrm{a})}$ & $\begin{array}{l}\text { Concentra- } \\
\text { tion, } g / L\end{array}$ \\
\hline Frit-165 (b) & 443.5 & 443.5 \\
\hline Zeolite $(c)$ & 12.6 & 12.8 \\
\hline $\mathrm{Fe}(\mathrm{OH})_{3}$ & 105.5 & 105.5 \\
\hline $\mathrm{Al}(\mathrm{OH})_{3}$ & 44.4 & 44.4 \\
\hline $\mathrm{MnCO}_{3}$ & 29.0 & -- \\
\hline$\left[\mathrm{Mn}\left(\mathrm{CHO}_{2}\right)_{2}\right]$ & -- & $36.6^{(d)}$ \\
\hline $\mathrm{Ni}\left(\mathrm{CHO}_{2}\right)_{2}$ & 10.7 & 10.7 \\
\hline $\mathrm{Ca}\left(\mathrm{CHO}_{2}\right)_{2}$ & 21.8 & 21.8 \\
\hline $\mathrm{SiO}_{2}$ & 20.3 & 20.3 \\
\hline $\mathrm{NaCHO}_{2}$ & 10.9 & 10.9 \\
\hline $\mathrm{NaNO}_{3}$ & 2.6 & 2.6 \\
\hline $\mathrm{Na}_{2} \mathrm{SO}_{4}$ & 1.0 & 1.0 \\
\hline $\mathrm{HCHO}_{2}$ & 27.9 & 4.9 \\
\hline Total & 730.4 & 715.0 \\
\hline
\end{tabular}

(a) Weight of chemicals used initially reported here, whereas concentration column represents the final feed slurry composition.

(b) Frit-165 composition ( -200 mesh)

$\begin{array}{lcc}\text { Oxide } & \text { Wt } \% \\ \mathrm{SiO}_{2} & & 68 \\ \mathrm{~B}_{2} \mathrm{O}_{3} & & 10 \\ \mathrm{Na}_{2} \mathrm{O} & 13 \\ \mathrm{Li}_{2} \mathrm{O} & 7 \\ \mathrm{MgO}^{2} & 1 \\ \mathrm{ZrO}_{2} & \frac{1}{100}\end{array}$

(c) Zeolite composition (Linde Ionsiv IE-95)

$$
\begin{array}{ll}
\frac{\text { Component }}{\mathrm{CaAl}} \mathrm{Si}_{4} \mathrm{O}_{12} \cdot \mathrm{CH}_{2} \mathrm{O} & \frac{w \mathrm{t} \%}{80} \\
\mathrm{Na}_{4} \mathrm{Ca} \mathrm{a}_{1.5} \mathrm{Al}_{3} \mathrm{Si}_{8} \mathrm{O}_{24} \cdot 8 \mathrm{H}_{2} \mathrm{O} & \frac{20}{100}
\end{array}
$$

(d) Value based on reaction of $\mathrm{MnCO}_{3}$ with $\mathrm{HCHO}_{2}$. 
removed. The plugs were usually started by a piece of foreign material such as a splinter of wood or small stones. The stones were narrow enough to pass through the feed transfer line strainer but too long to pass through the $U$-tube of the flow sensor. These garbage materials usually entered the feed make-up tank as an impurity in the muddy ferric hydroxide.

The PSCM-8 experiment processed a 40-wt\% solids, high-alumina, formate feed composition shown in Table 9. During the 232-hour experiment, this feed system was used for $\sim 42$ hours, accounting for about $1900 \mathrm{~L}$ of the $\sim 15,400 \mathrm{~L}$ of slurry fed to the PSCM. The remaining $\sim 13,500 \mathrm{~L}$ of slurry was fed to the melter using the pressurized loop system previously described. The slurry was prepared in three separate make-up vessels, two 2,900-L vessels and a 12,500-L vessel. The Moyno pump system had no problem pumping the slurry from the two smaller vessels. However, the slurry from the 12,500-L vessel contained some hard, granular ferric hydroxide that would not stay suspended. A large proportion of this material entered TK-60 during the first feed transfer and settled in the pump and feedline. The feed slurry, unlike previous feeds, was very coarse and separated quickly into an insoluble solids phase and a relatively clear supernate solution.

The PSCM-9 experiments processed a 40-wt\% solids, alkaline waste composition containing the frit-131 shown in Table 10. The experiment lasted 98 hours, during which $\sim 4,250 \mathrm{~L}$ of slurry was fed to the melter. The pump worked well but the flowmeter again showed tendencies of plugging at flow rates $<1.0 \mathrm{~kg} / \mathrm{min}$. On four separate occasions, flow to the melter was stopped by plugs forming in the flowmeter or adjacent tubing. The ability of the flow control system also was affected by the plugging as shown in Figure 18, where the actual feed rate versus time is compared to the setpoint value.

In summary, the positive displacement pump system has been operated for $\sim 755$ hours, delivering $20,350 \mathrm{~L}$ of various slurries to the PSCM. The system proved quite reliable in pumping slurries very close to the setpoint value at rates $>1.0 \mathrm{~kg} / \mathrm{min}$. At rates $<1.0 \mathrm{~kg} / \mathrm{min}$ or in which very fast-settling solids were present, the flowmeter was prone to plugging. Many of the pluggages were from foreign material that should have been prevented from entering the feed system, such as wood splinters or small stones lodging in the entrance of the flowmeter. 
TABLE 9. Composition of Simulated TDS Hi-Al-Formic Acid Waste and Frit-165 Waste Slurry (basis: 1000-L batch)

\begin{tabular}{|c|c|c|}
\hline Compound & Weight, $\mathrm{kg}^{(\mathrm{a})}$ & $\begin{array}{l}\text { Concentra- } \\
\text { tion, } g / L\end{array}$ \\
\hline Frit-165 $(\mathrm{b})$ & 347.5 & 347.5 \\
\hline Zeolite ${ }^{(c)}$ & 14.3 & 14.3 \\
\hline $\mathrm{Fe}(\mathrm{OH})_{3}$ & 25.8 & 25.8 \\
\hline $\mathrm{Al}(\mathrm{OH})_{3}$ & 105.5 & 105.5 \\
\hline $\mathrm{MnCO}_{3}$ & 20.9 & -- \\
\hline$\left[\mathrm{Mn}\left(\mathrm{CHO}_{2}\right)_{2}\right]$ & -- & $26.4^{(d)}$ \\
\hline $\mathrm{Ni}\left(\mathrm{CHO}_{2}\right)_{2}$ & 5.6 & 5.6 \\
\hline $\mathrm{Ca}\left(\mathrm{CHO}_{2}\right)_{2}$ & 2.9 & 2.9 \\
\hline $\mathrm{SiO}_{2}$ & 6.3 & 6.3 \\
\hline $\mathrm{NaCHO}_{2}$ & 15.4 & 15.4 \\
\hline $\mathrm{Na}_{2} \mathrm{SO}_{4}$ & 1.0 & 1.0 \\
\hline $\mathrm{HCHO}_{2}$ & 20.3 & 1.7 \\
\hline Total & 565.5 & 552.4 \\
\hline
\end{tabular}

(a) Weight of chemicals used initially reported here, whereas concentration column represents the final feed slurry composition.

(b) Frit-165 composition (-200 mesh)

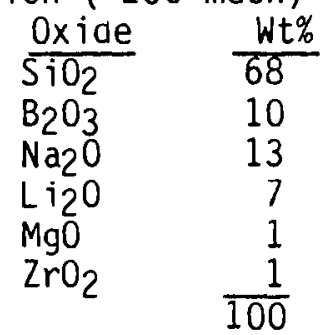

(c) Zeolite composition (Linde Ionsiv IE-95)

$$
\begin{aligned}
& \frac{\text { Component }}{\mathrm{CaAT}_{2} \mathrm{Si}_{4} \mathrm{O}_{12} \cdot 6 \mathrm{H}_{2} \mathrm{O}} \quad \frac{\text { Wt \% }}{80}
\end{aligned}
$$

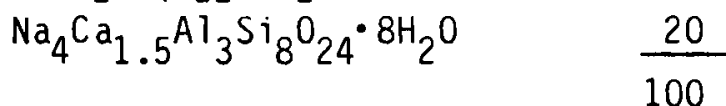

(d) Value based on reaction of $\mathrm{MnCO}_{3}$ with $\mathrm{HCHO}_{2}$. 
TABLE 10. Composition of Simulated West Valley Neutralized Waste and Frit-131

\begin{tabular}{|c|c|c|}
\hline Compound & Weight, $\mathrm{kg}^{(\mathrm{a})}$ & $\begin{array}{l}\text { Concentra- } \\
\text { tion, } g / L\end{array}$ \\
\hline $\begin{array}{l}\text { Frit-131(b) } \\
\mathrm{Fe}(\mathrm{OH})_{3}\end{array}$ & $\begin{array}{r}308.8 \\
86.7\end{array}$ & $\begin{array}{c}308.8 \\
86.7\end{array}$ \\
\hline $\mathrm{FePO}_{4} \cdot 2 \mathrm{H}_{2} \mathrm{O}$ & 62.2 & 62.2 \\
\hline $\mathrm{Cr}(\mathrm{OH})_{3}$ & 7.0 & 7.0 \\
\hline $\mathrm{NiO} \cdot \mathrm{H}_{2} \mathrm{O}$ & 3.6 & 3.6 \\
\hline $\mathrm{A} 1(\mathrm{OH})_{3}$ & 1.6 & 1.6 \\
\hline $\operatorname{RE}(\mathrm{NO})_{x}(\mathrm{c})$ & 5.6 & 6.6 \\
\hline $\mathrm{MnCO}_{2}$ & 3.9 & 3.9 \\
\hline $\mathrm{Na}_{2} \mathrm{SO}_{4}$ & $\leq 3.8^{(d)}$ & 3.8 \\
\hline $\mathrm{Nd}\left(\mathrm{NO}_{3}\right)_{3} \cdot 6 \mathrm{H}_{2} \mathrm{O}$ & 16.2 & 16.2 \\
\hline $\mathrm{NaNO}_{3}$ & 29.2 & 29.2 \\
\hline $\mathrm{NaOH}$ & 0.43 & 0.43 \\
\hline $\mathrm{NaCl}$ & (c) & $\geq 0.02$ \\
\hline $\mathrm{CSNO}_{3}$ & 0.62 & 0.62 \\
\hline $\mathrm{Sr}\left(\mathrm{NO}_{3}\right)_{2}$ & 0.34 & 0.34 \\
\hline $\mathrm{Na}_{2} \mathrm{MoO}_{4} \cdot 2 \mathrm{H}_{2} \mathrm{O}$ & 2.8 & 2.8 \\
\hline $\mathrm{NaI}$ & 0.30 & 0.30 \\
\hline $\mathrm{SiO}_{2}$ & 51.5 & 51.5 \\
\hline Total & 585.6 & 585.6 \\
\hline
\end{tabular}

(a) Frit-131 composition (-200 mesh)

\begin{tabular}{|c|c|}
\hline 0xide & Wt\% \\
\hline $\mathrm{SiO}_{2}$ & 57.9 \\
\hline $\mathrm{B}_{2} \mathrm{O}_{3}$ & 14.7 \\
\hline $\mathrm{Na}_{2} \mathrm{O}$ & 17.7 \\
\hline $\mathrm{Li}_{2} \mathrm{O}$ & 5.7 \\
\hline $\mathrm{MgO}$ & 2.0 \\
\hline $\mathrm{TiO}_{2}$ & 1.0 \\
\hline $\mathrm{La}_{2} \mathrm{O}_{3}$ & 0.5 \\
\hline $\mathrm{Zr} 0$ & 0.5 \\
\hline & 100 \\
\hline
\end{tabular}

(b) Rare Earth Nitrate Mix Nominal Oxide Composition

$\begin{array}{lr}\frac{\text { Oxide }}{\mathrm{CeO}_{2}} & \frac{W t \%}{48.0} \\ \mathrm{La}_{2} \mathrm{O}_{3} & 24.0 \\ \mathrm{Nd}_{2} \mathrm{O}_{3} & 17.0 \\ \mathrm{Pr}_{6} \mathrm{O}_{11} & 5.0 \\ \mathrm{Sm}_{2} \mathrm{O}_{3} & 3.0 \\ \mathrm{Gd}_{2} \mathrm{O}_{3} & 2.0 \\ \mathrm{YZ}_{3} \mathrm{~S}_{3} & 0.2 \\ \mathrm{Misc} & 0.8 \\ & 100\end{array}$

(c) Sulfate level determined by impurity level in $\mathrm{Fe}(\mathrm{OH})_{3}$.

(d) Chloride impurity level in $\mathrm{Fe}(\mathrm{OH})_{3}$ usually greater than flowsheet value. 


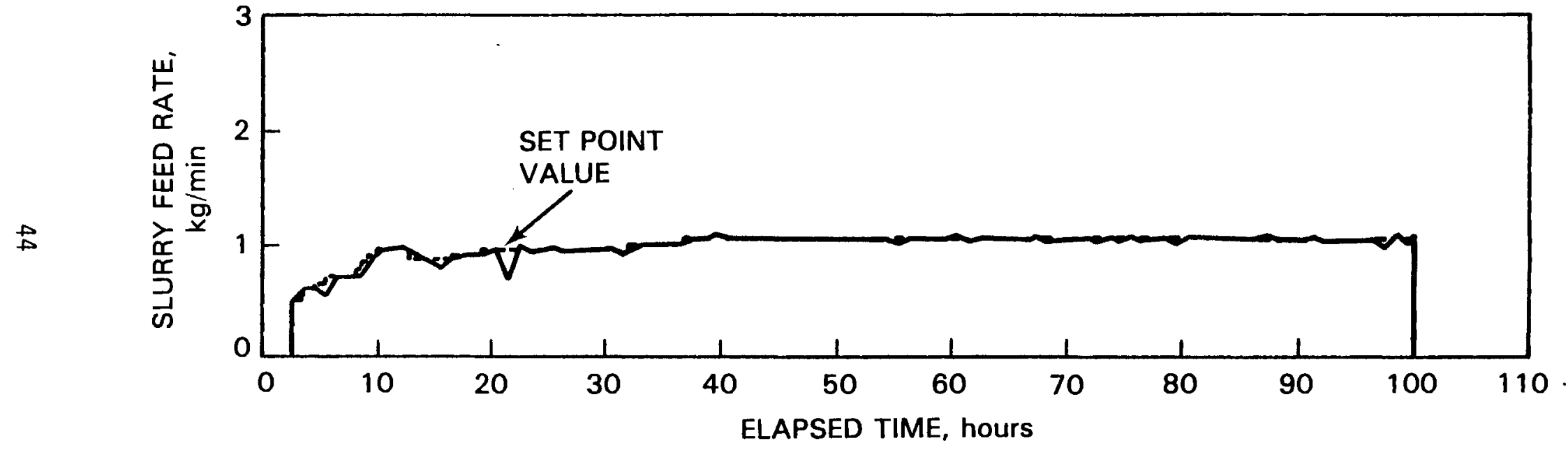

FIGURE 18. Feed Rate Versus Time: PSCM-9 Experiment 


\section{REFERENCES}

Dabolt, R. J., and K. E. Plummer. 1980. Design of Air-Lift Systems for Transfer and Measurement of Radioactive Liquids. AGNS-35900-3.2-77, A 11 ied General Nuclear Services, Barnwell, South Carolina.

Goodlet, C. B. 1968. Transfer of Radioactive Slurries. DP-1136, Savannah River Laboratory, Aiken, South Carolina.

Harrison, P. 1980. "Flow Measurement--A State-of-the-Art Review." Chemical Engineering 1(14):99-104.

Karassik, I. J., W. C. Krutzsch, W. H. Fraser, and J. P. Messina (eds.). 1976. Pump Handbook. McGraw-Hill, New York.

Lazenby, B. 1980. "Level Monitoring and Control." Chemical Engineering $1(14): 88-96$.

Miller, F. A. 1981. Design and Performance of a Full-Scale Spray Calciner for Nonradioactive High-Level Waste Vitrification Studies. PNL-3742, Pacific Northwest Laboratory, Richland, Washington.

Perry, R. H., and C. H. Chilton (eds.). 1950. Chemical Engineers' Handbook, fifth ed., McGraw-Hill, Roca Baton, Florida.

"Pump and Valve Selector." 1971. In Chemical Engineering Deskbook. McGraw-Hi11, New York. 
. 


\section{APPENDIX A}

VISCOSITY AND SETTLING MEASUREMENTS OF FEED SAMPLES 
APPENDIX A

\section{VISCOSITY AND SETTLING MEASUREMENTS OF FEED SAMPLES}

Viscosity and settling measurements of feed samples taken over the last 30 months have been made. The results are tabulated in Table A.1. The viscosity measurements were measured with a rotating spindle viscometer. Due to the non-Newtonian, thixotropic behavior of the feed, the standard deviation of the viscosities is approximately equal to the value itself in most cases. Therefore, at best, only order-of-magnitude comparisons can be made. The viscosities generally increase with temperature. The compositions of Samples 1 and 2 differed only in that Sample 2 contained Frit-211. This increased the oxide loading by a factor of five, but did not appreciably increase the fluid viscosity. The TDSM Waste with Frit-131 (Samples 3 through 7) generally had higher viscosities than either of the other feed samples. Samples 9 and 10 differed in that Sample 9 was a slurry containing $20 \%$ less solids than Sample 10 . The viscosity of Sample 12, the West Valley simulated waste and frit slurry, was consistent with the other neutralized wastes. Based on these results, it appears that keeping the feed as cool as is practicable minimizes pumping or transfer requirements.

Settling percent was determined by allowing the samples to stand undisturbed for 24 hours and then measuring the amount of clear supernate that existed. Values are presented in Table A.l as percent of total sample volume. All samples settled to the same extent with the exception of Sample 11. As was discussed in the main body of this report, the high aluminum waste slurry was very coarse and separated quickly into an insoluble phase and a clear supernate phase. The value given for Sample 9 was taken after the sample had stood for five days. This value then may be taken as the maximum percent of settling that can be expected. 
TABLE A.1. Viscosity and Settling Measurements of Feed Samples

\begin{tabular}{|c|c|c|c|c|c|c|c|}
\hline \multirow[b]{2}{*}{ Sample } & \multirow{2}{*}{$\begin{array}{l}\text { Date } \\
\text { of } \\
\text { Run } \\
\end{array}$} & \multirow{2}{*}{$\begin{array}{l}\text { Composition } \\
\text { Reference } \\
\text { Table Number } \\
\end{array}$} & \multirow{2}{*}{$\begin{array}{l}\text { Solids } \\
\text { Loading, } \\
\text { g-oxide/L }\end{array}$} & \multicolumn{3}{|c|}{$\begin{array}{l}\text { Viscosity } \\
\text { Centipoise }\end{array}$} & \multirow{2}{*}{$\begin{array}{r}\text { Percent } \\
\text { Settled } \\
\text { After } 24 \mathrm{~h} \\
\end{array}$} \\
\hline & & & & $27^{\circ} \mathrm{C}$ & $48^{\circ} \mathrm{C}$ & $75^{\circ} \mathrm{C}$ & \\
\hline 1. SRL-TDS Waste & $03 / 80$ & 2 & 100 & 1.6 & 4 & 5 & NA(a) \\
\hline $\begin{array}{l}\text { 2. SRL-TDS Waste } \\
\text { and Frit-2I I }\end{array}$ & $09 / 80$ & 4 & 511 & 5 & 4 & 42 & NA \\
\hline $\begin{array}{l}\text { 3. TDSM Waste and } \\
\text { Frit-I3I }\end{array}$ & $11 / 80$ & 5 & 470 & 23 & $>530$ & $>530$ & $N A$ \\
\hline $\begin{array}{l}\text { 4. TDSM Waste and } \\
\text { Frit-131 }\end{array}$ & $12 / 80$ & 5 & 470 & 46 & 39 & 111 & 7 \\
\hline $\begin{array}{l}\text { 5. TDSM Waste and } \\
\text { Frit-I3I }\end{array}$ & $01 / 81$ & 5 & 470 & 260 & $>530$ & $>530$ & 10 \\
\hline $\begin{array}{l}\text { 6. TDSM Waste and } \\
\text { Frit-I3I }\end{array}$ & $03 / 81$ & 5 & 470 & 103 & 139 & $>530$ & 10 \\
\hline $\begin{array}{l}\text { 7. TDSM Waste and } \\
\text { Frit-I3I }\end{array}$ & $06 / 81$ & 5 & 470 & 37 & 77 & 174 & 8 \\
\hline $\begin{array}{l}\text { 8. Formic Acid waste } \\
\text { and Frit-I3I }\end{array}$ & $07 / 81$ & 6 & 480 & 19 & 16 & 184 & 11 \\
\hline $\begin{array}{l}\text { 9. Formic Acid Waste } \\
\text { and Frit- } 165\end{array}$ & $03 / 82$ & 6,7 & 480 & 14 & 38 & 25 & $25(b)$ \\
\hline $\begin{array}{l}\text { 10. Formic Acid Waste } \\
\text { and Frit-165 }\end{array}$ & $05 / 82$ & 8 & 621 & 75 & 86 & 94 & 7 \\
\hline $\begin{array}{l}\text { 11. Hi-Al Formic Acid } \\
\text { Waste and Frit-165 }\end{array}$ & $06 / 82$ & 9 & 480 & 5 & 6 & 8 & 43 \\
\hline $\begin{array}{l}\text { 12. West Valley Neu- } \\
\text { tralized Waste } \\
\text { and Frit-131 }\end{array}$ & $08 / 82$ & 10 & 480 & 69 & 68 & 69 & 9 \\
\hline
\end{tabular}

(a) Data not available.

(b) Samples measured after five days. 
APPENDIX B

PUMPS AND TRANSFER DEVICES 
APPENDIX B

\section{PUMPS AND TRANSFER DEVICES}

Most fluid transfer devices can be classified into three major categories:

1) centrifugal pumps

2) positive-displacement pumps

3) fluid displacement (airlift).

Advantages and disadvantages of each of these types of transfer devices for a liquid-fed ceramic melter are discussed separately. Special emphasis is given to considerations for transfer of slurries.

\section{CENTRIFUGAL PUMPS}

Centrifugal pumps are used in a wide range of services in most industries, but they have limitations at low flows and high viscosities. Some primary advantages of centrifugal pumps are:

- simplicity (only one moving part--the impeller)

- low maintenance

- uniform (non-pulsating) flow.

In general, situations unsuitable for centrifugal pumps are (Chemical Engineering Deskbook 1971): 1) flows <15 or $20 \mathrm{~L} / \mathrm{min}(4$ or $5 \mathrm{gpm}$ ) and 2) very viscous ( $>2,000$ centipoise) and non-Newtonian fluids.

Typical flow characteristics for a centrifugal pump are shown in Figure B.1. At a fixed speed, the pump will operate along its characteristic curve and at no other points. For example, the pump will operate at $34 \mathrm{gpm}$ while generating $154 \mathrm{ft}$ of head. If the head is increased to $180 \mathrm{ft}, 16 \mathrm{gpm}$ will be delivered. It is impossible to operate at $150 \mathrm{ft}$ of head and $8 \mathrm{gpm}$ unless the pump discharge is throttled so that $150 \mathrm{ft}$ of head is actually generated within the pump. On the other hand, pumps with variable-speed drivers can change the characteristic curve by changing the pump speed.

When pumping slurries with centrifugal pumps, several design considerations are (Karassik et al. 1976): 


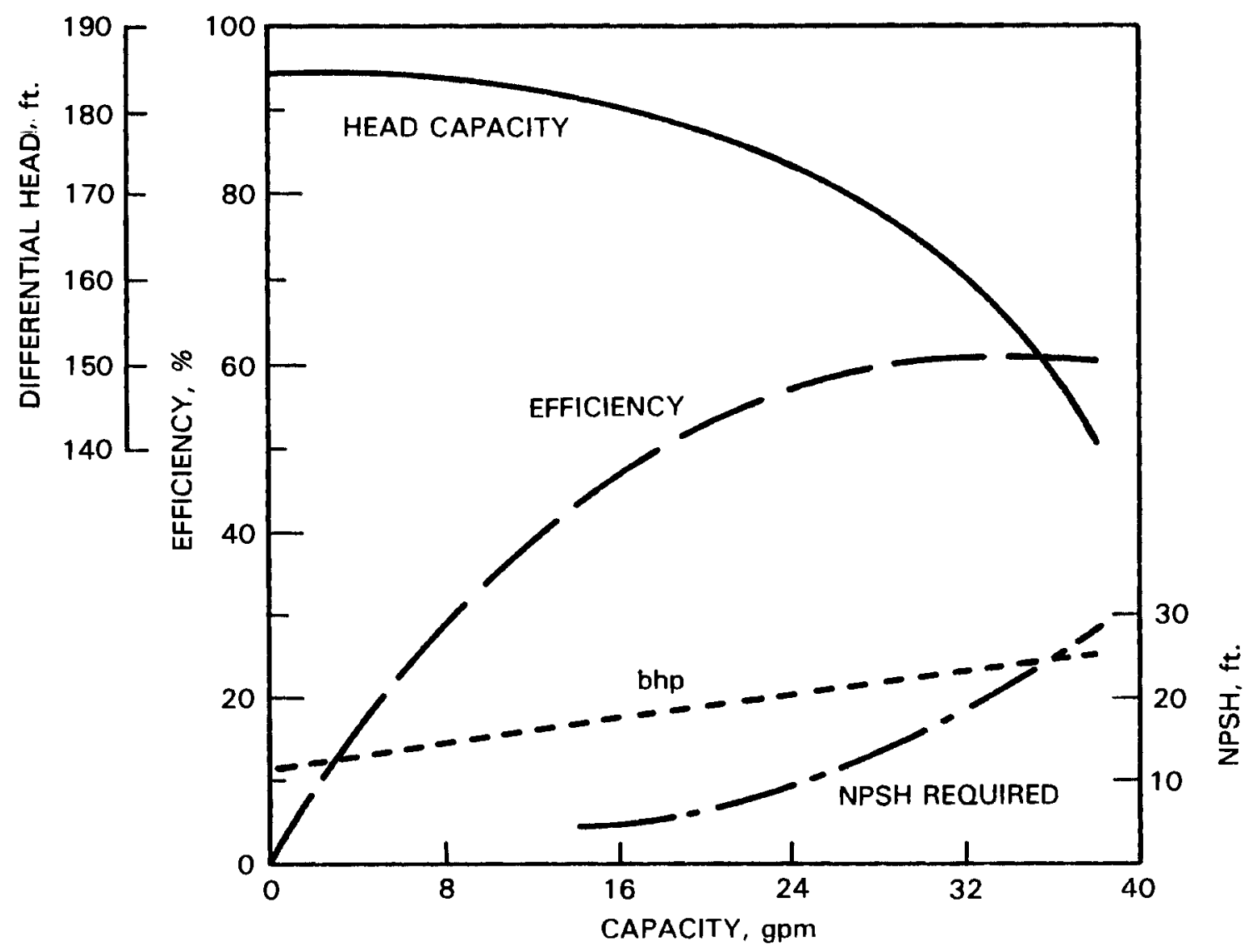

FIGURE B.1. Flow Characteristics of Centrifugal Pumps

- construct the pump with abrasion/corrosion-resistant materials

- provide generous wear allowances on all parts subjected to abrasion

- use hydraulic designs that minimize wear

- consider consequences of worn shaft seals and take steps to minimize this problem.

\section{POSITIVE-DI SPLACEMENT PUMPS}

The primary characteristic of positive-displacement pumps is the direct relationship between the motion of the pumping element and the quantity of liquid moved. In contrast, flow rate with a centrifugal pump is determined by the resistance to flow in the discharge (at a given pump speed). Ideally, 
flow rate with a positive-displacement pump is determined solely by the pumping element's speed. In actual practice, leakage through dynamic seals or "slip" increases with increased pressure and causes a drop in flow rate from the ideal. Volumetric efficiency, the actual flow divided by the ideal flow, should be between 85 and $95 \%$ for a properly-operating positive-displacement pump (Chemical Engineering Deskbook 1971).

There are two basic types of positive-displacement pumps: reciprocating and rotary. Reciprocating pumps, such as diaphragm or piston pumps, produce a pulsating flow. Rotary pumps, such as gear or screw pumps, produce a more continuous flow.

Piston pumps are considered for low abrasion mixtures such as coal slurries. They are suitable for high-volume flows and pressures up to 2000 psig with solids sizes limited to less than 8 mesh (Karassik et al. 1976).

Diaphragm pumps have, as the displacement element, a flexible membrane fabricated from elastomers, plastics or metals. A major advantage of this type of pump is that no packings or dynamic seals are required because the drive mechnism is isolated from the fluid being pumped by the diaphragm. For this reason, the diaphragm pump is used when leakage of the process fluid cannot be tolerated. The check valves of a diaphragm pump are the only part subject to abrasive wear by solids.

Gear pumps have two or more impellers in the form of toothed gear wheels. Because of the extremely small clearances between the gears, this type of pump is normally used for liquids free of frit or abrasive solids.

Screw pumps have helical elements that mesh as their contact points progress axially down the screws, creating a pumping action with little pulsation. If constructed of proper materials, this type of pump can be used for pumping fine slurries.

Peristaltic-type tubing pumps have characteristics of both reciprocating and rotary pumps. These pumps have a flexible tubing that is compressed by two rotating wheels, producing a flow in the direction of the rotating 
wheels. No seals are required. Susceptibility of the flexible tubing to abrasion and radiation damage, however, limits the use of this type of pump in the nuclear industry.

\section{FLUID-DISPLACEMENT DEVICES}

Fluid-displacement devices (rather than mechanical-action devices), use a secondary fluid to move the primary fluid. These types of devices include jet pumps, airlifts and "acid eggs."

A jet pump makes use of the momentum of one fluid to move another using a venturi. An airlift uses compressed air injected near the bottom of a submerged pipe to produce a liquid and air mixture that is lighter than the liquid alone and, therefore, rises. Design aspects of airlifts are discussed elsewhere (Debolt 1980). An "acid egg" consists of a pressure vessel (sometimes egg-shaped) which can be filled with the liquid to be transferred and then pressurized with air (Perry 1950). The discharge pipe extends to the bottom of the vessel, and liquid is forced up through the pipe by the air pressure in the vessel. Flow control can be arranged for automatic or semi-automatic operation.

The principal advantage with fluid-displacement devices is that there are no moving parts. Also, there are no electrical connections or parts subject to radiation damage. Fluid-displacement devices are usually limited to low head-pressure applications.

\section{PUMP WEAR}

Several requirements must be considered when selecting materials to resist abrasive wear. The material must withstand not only abrasion but also impact, fatigue stresses, shock loads and corrosion. The predominant factor causing wear must be recognized and understood before selecting the material of construction.

Abrasive wear in pumps can be generalized into three types (Karassik et a). 1976): 
- Gouging abrasion occurs when coarse particles impinge with such force that high-impact stresses occur, tearing relatively large pieces from the wearing surfaces.

- Grinding abrasion results from a crushing action on particles between two rubbing surfaces.

- Erosion abrasion occurs when particles (sometimes parallel to the surface) impinge on the wearing surface.

The rate of wear depends on the material of construction and the mixture being pumped. Considerations affecting wear are:

- Size--larger particle sizes increase wear. To minimize wear, the sizes of particles in a melter feed slurry must be reduced.

- Shape--angular-shaped particles cause greater wear than smooth particles (ground-glass-frit particles have angular shapes). Increased particle concentration increases wear.

- Hardness--when the particle hardness exceeds that of the pump material, wear increases rapidly. A comparison of approximate hardness values is shown in Figure B.2. Glass (likely to be similar to frit particles) has a hardness of -380 on the Brinell scale, whereas 316 SS has a hardness of 115 . A pump material harder than 380 is probably necessary to minimize wear when pumping glass frit.

- Velocity--particle velocity and angle of impact are major considerations in material selections. Materials with high elastic limits can resist direct impact. Materials with high hardness are used for relatively low impact.

- Kinetic Energy--to reduce wear, it is essential to keep the kinetic energy of the particles as low as possible. The total head requirements of the system should be minimized so that a low pump rpm can be used. Vertical or sloped transfer lines can be used to prevent solids from settling out when using a low-fluid velocity. 


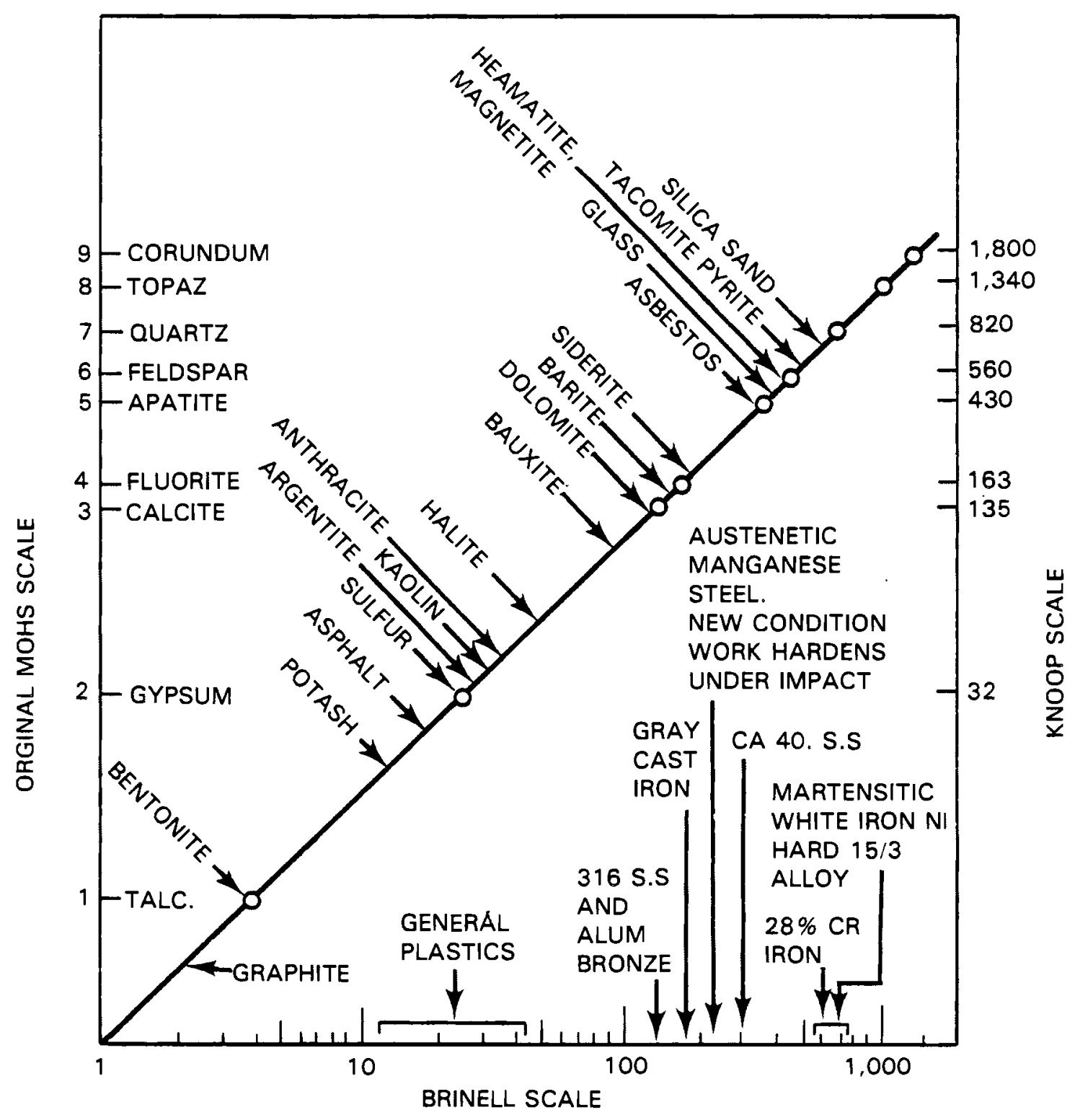

FIGURE B.2. Approximate Comparison of Hardness Values of Various Common Ore Materials and Metals (Karrassik et a1. 1976)

\section{PUMP MATERIALS}

For high-impact gouging abrasion, austenitic manganese steel (12 to $14 \%$ manganese) of 220 hardness on the Brinell scale (see Figure B.2) is often used (Karassik et a1. 1976). This material has high toughness, work hardens under 
impact, is free from high-residual stresses in castings and can be machined and welded by orthodox methods. This material is used for construction of dredge and heavy-duty gravel pumps.

For grinding and abrasion erosion, where the particles are coarse and impact is moderately low, martensitic white irons such as $\mathrm{Ni}$-hard $(4 \% \mathrm{nickel}$, $2 \%$ chrome) and 15/3 alloy (15\% chrome, 3\% molybdenum) are used. These cast irons have a hardness of 550 to 650 on the Brinell scale (see Figure B.2). Heat treatment can yield a hardness of 730 on the Brinell scale in special cases. The harder the material, the more brittle it will be. These hard irons are machine ground for use in constructing standard gravel pumps as well as finer-mesh slurry pumps.

Castable silicon carbide ceramics, with a hardness of 9.5 on the mohs scale, are used in fine mesh (-20 mesh) slurry pump construction (Karassik et al. 1976). This material gives excellent resistance to erosion abrasion where there is negligible impingement and impact. It has excellent corrosion and temperature resistance, but is extemely brittle and expensive to produce.

Rubbers and urethanes are used extensively in many industries for slurry pumps, but their susceptibility to radiation damage limits their use in the nuclear industry.

\section{PUMP SEALS}

Sealing abrasive mixtures under pressure has long been a problem. It is especially serious when transferring radioactive slurries, due to the possibility of spreading contamination.

Often, conventional shaft-sealing techniques are not suitable for use with radioactive slurries. Seals that are pressurized with water to keep out particles cause dilution of the slurry being transferred, which may be undesirable. Mechanical seals and packed boxes that are not flushed with water require precise adjustment and undergo excessive wear with abrasive slurries. So, unless dilution or leakage of the material being transferred can be tolerated, alternative methods to shaft seals are required (such as pumps that do not require shaft seals). 
Vertical cantilevered-type centrifugal pumps have been used for the transfer of radioactive slurries (Goodlet 1966). These pumps extend into the tank with the motor driver mounted over the pump on top of the tank. All seals and bearings are above and out of the slurry, permitting long-term operation without seal or bearing replacement; there is also little risk of contamination leaks. These pumps have the advantage of not having to seal against the liquid and of being self-draining when the tank is drained. When pumping from the bottom of a deep tank, intermediate and foot bearings may be required. If solids are present, bearings can sometimes be avoided by using tapered shafts and double-discharge volumes to balance the hydraulic radial thrust (Perry 1950). 
APPENDIX C

TANK LEVEL MEASUREMENT 
APPENDIX C

TANK LEVEL MEASUREMENT

Tank level is one of the most important parameters to be measured. Many of the devices normally used in chemical industries are not suitable for level measurement of radioactive slurries. Desirable characteristics for level devices for radioactive slurries include: 1) remote indication or control, 2) no mechanical moving parts, 3) a greater than $2 \%$ accuracy, and 4) a noncontacting ability. These requirements eliminate all level devices except ultrasonics, radar, radiation, load cells and, possibly, bubbler devices (air. purge) (Lazenby 1980).

Similar to radar, an ultrasonic system produces a pulse of energy at the resonant frequency of a piezoelectric crystal mounted in a transducer (the pulse of energy transmitted reflects off an object back to the source). The elapsed time between sending and receiving a pulse is a measure of the distance traveled in one medium. There are some limits to the use of an ultrasonic level-indicating system. With liquids, the transducer must be accurately positioned to ensure that the reflected signal is directed at the transducer. Turbulent liquid may reflect the pulse of energy back to the receiver only periodically, thus giving an intermittent reading. In this case, a pipe that extends below the surface of the liquid through which the energy pulse is transmitted can be used to ensure a smooth surface.

Radiation devices measure the level of radiation transmitted through the tank wall at various locations and convert that reading to a corresponding tank level. The advantage of this type of device is that no openings have to be made through the tank wall.

A load cell is normally comprised of a number of resistance strain gauges that can be used to measure the total weight of container and contents. 
Deduction of the weight of the container leaves the weight of contents. The specific gravity of the contents must be known to convert weight into volume.

In an air purge or bubbler device, compressed air is forced through a tube that leads to the bottom of the tank. The air pressure required to cause the air to bubble from the bottom of the tube is equal to the pressure at the bottom of the tank due to the level of the liquid. This type of device must contact the liquid. Also, drying of the liquid by the air bubbles can cause dried solids to form on the end of the bubbler tube, which eventually restricts the air flow and results in erroneous readings or in complete blockage. Humidified air may eliminate or reduce this drying problem. 
APPENDIX D

FLOW MEASUREMENT 
APPENDIX D

\section{FLOW MEASUREMENT}

For flow measurement of radioactive slurries, nonmechanical flowmeters are usually preferred. In addition, many types of flowmeters require an exceedingly small orifice when measuring flow rates less than $\sim 2-L / h$, a highly undesirable rate for measuring slurry flows. These restraints may limit the choice of flowmeters for radioactive slurries to electroamagnetic flowmeters, mass flowmeters or, possibly, ultrasonic flowmeters.

Electromagnetic flowmeters function on the principle that liquid moving through a magnetic field induces a voltage that can be measured and converted to a flow rate. There are no moving parts and no large head loss. Manufacturers claim that recent improvements in the design have greatly reduced the problem of zero drift, but operators still need to be aware of the problem.

Mass flowmeters have an obstruction less "U-shaped" tube that is vibrated at its natural frequency. The velocity of the flowing fluids, combined with the angular movement of the tube, causes the tube to twist. The amount of twist is measured by electro-optical switches and related to the mass flow rate of the material. Nothing comes in contact with the flowing fluid except the inside wall of the tube, which is made of stainless steel or other corrosion/erosion-resistant material.

With ultrasonic flowmeters, a sound wave transmitted against the direction of flow is decelerated, and a sound wave transmitted with the direction of flow is accelerated. Difficulties with this method include variations in temperature and density that affect the speed of sound and can result in erroneous readings. Also, since the fluid velocity is determined by the flowmeter along the path of the sound wave, and the volumetric flow rate is deduced from the whole area of the pipe, the velocity profile affects the accuracy of metering. This is not a problem, however, under turbulent conditions. 
Three practical applications of ultrasonics are currently available: 1) frequency difference systems, 2) leading edge systems, and 3) Doppler Systems (Harrison 1980). Generally, accuracies of $\pm 1 \%$ have been claimed.

For the frequency difference method, ultrasonic pulses are transmitted in the downstream direction between a pair of transducers and in the upstream direction between a further pair of transducers. The reception of one pulse triggers another pulse, generating a sequence of pulses. The frequency difference between the two pairs is proportional to the fluid velocity. This design avoids effects of temperature and density fluctuations, but is more suitable for larger-diameter pipes.

In the leading edge system, sound waves are transmitted simultaneously in the upstream and downstream directions, and transit times are measured. The leading edge of the pulse is used for this measurement (hence the name), and the fluid velocity can be determined independently of the effects of temperature and density on the speed of sound. This method is also more suitable for large pipes.

In the Doppler system, sound waves reflected from moving objects have a different frequency than the incident beam. This frequency change is proportional to the velocity of the particle causing the scattering, and is inversely proportional to the velocity of sound. Therefore, temperature and density fluctuations affecting sound velocity will affect the velocity indications of the flowmeter. The main attraction of this method is that it can be used in small pipes of $-1 / 2$ in. The fluid must, however, contain a sufficient number of evenly distributed particles. 
PNL -4423

UC-70

DISTRIBUTION

No. of

Copies

OFFSITE

27 DOE Technical Information Center

R. Y. Lowrey

DOE Albuquerque Operations Office

P.0. Box 5400

Albuquerque, NM 87185

S. A. Mann

DOE Chicago Operations and Region Office

Argonne, IL 60439

J. 0. Neff

DOE Columbus Program Office

505 King Avenue

Columbus, $\mathrm{OH} 43201$

W. E. Mott

DOE Division of Environmental

Control Technology

Washington, DC 20545

J. P. Hamric/J. B. Whitsett

DOE Idaho Operations office

550 2nd St.

Idaho Falls, ID 34801

7 DOE Nuclear Waste Management and Fuel Cycle Programs

NE-30, GTN

Washington, DC 20545

C. R. Cooley/D. G. Boyer

R. B. Chitwood

C. H. George/C. A. Heath

S. Meyers/R. Romatowski

A. F. Perge

R. W. Ramsey

R. D. Walton
No. of

Copies

6 DOE Office of Defense Waste and Byproducts

DP-12, GTN

Washington, DC 20545

G. H. Daly

J. E. Dieckhoner

D. J. McGoff

G. K. Oertel

A. L. Taboas

V. G. Trice

D. L. Vieth

DOE Nuclear Waste Management Programs

NE-332, GTN

Washington, DC 20545

S. W. Ahrends/D. E. Large DOE Oak Ridge Operations Office P.0. Box E

Oak Ridge, TN 37830

S. G. Harbinson

DOE San Francisco Operations Office

1333 Broadway

0akland, CA 94612

W. B. Wilson/E. S. Goldberg

DOE Savannah River Operations Office

P.0. Box A

Aiken, SC 29801

R. P. Whitfield/

T. B. Hindman, Jr.

DOE Savannan River Operations Office

P.0. Box A

Aiken, SC 29801 
No. of

Copies

Los Alamos Scientific Laboratory Reference Library

P.0. Box 1663

Los Alamos, NM 87544

D. B. Rohrer/R. D. Smith Division of Waste Management Nuclear Regulatory Commission Washington, DC 20555

R. E. Cunningham

Office of Nuclear Safety Materials and Safeguards Nuclear Regulatory Commission Room 562, 7915 Eastern Avenue Silver Springs, MD 20910

J. A. Buckham/A. Williams Allied-General Nuclear Services P.0. Box 847

Barnwell, SC 29812

M. J. Steindler/L. E. Trevorrow/ J. H. Kittel

Argonne National Laboratory

9700 South Cass Avenue

Argonne, IL 60439

W. Carbiener/N. E. Carter

Battelle Memorial Institute

Office of Nuclear Waste I solation

$505 \mathrm{King}$ Avenue

Columbus, $\mathrm{OH} 43201$

Research Library

Battelle Memorial Institute

505 King Avenue

Columbus, $\mathrm{OH} 43201$

R. Maher, Program Manager Waste Management Programs

Savannah River Plant

E. I. du Pont de Nemours \& Company, Inc.

Aiken, SC 29801
No. of

Copies

5 E. I. du Pont de Nemours \& Company, Inc.

Savannah River Laboratory

Aiken, SC 29801

M. D. Boersma/H. L. Hull

J. L. Crandall/R. G. Garvin

L. W. Meyer

D. L. McIntosh/J. Kelley

S. Mirshak

A. L. Ayers/G. B. Levin

EG\&G Idaho

P.0. Box 1625

Idaho Falls, ID 83401

R. Williams

Electric Power Research

Institute

3412 Hillview Avenue

Palo Alto, CA 94304

J. L. Larocca, Chairman

Engineering Research and

Development Authority

Empire State Plaza

Albany, NY 12223

2 Environmental Protection Agency

Technological Assessment

Division (AW-559)

Office of Radiation Programs

U.S. Environmental Protection Agency

Wasnington, DC 20460

G. L. Ritter/ J. R. Berreth

Exxon Nuclear Idaho

P.0. Box 2800

Idaho Falls, ID 83401

File Copy

Exxon Nuclear Idaho

P.0. Box 2800

Idaho Falls, ID 83401 
No. of

Copies

J. Campbe11/J. D. Tewhey

Lawrence Livermore Laboratory

P.0. Box 808

Livermore, CA 94550

R. Roy

202 Materials Research Laboratory

Pennsylvania State University University Park, PA 16802

C. J. Kershner

Monsanto Research Corporation

Mound Laboratory

P.0. Box 32

Miamisburg, $\mathrm{OH} 45342$

J. P. Duckworth

Plant Manager

Nuclear Fuels Services, Inc.

P.0. Box 124

West Valley, NY 14171

5 Oak Ridge National Laboratory

P.0. Box $Y$

Oak Ridge, TN 37830

R. E. Blanco

J. 0. Blomeke

D. E. Ferguson

A. L. Lotts

R. S. Lowrie

A. B. Martin

Rockwell International

Energy Systems Group

8900 DeSoto Avenue

Canoga Park, CA 91304

H. Recht

Dept. 737-710

Atomics International Division

Rockwell International

P.0. Box 309

Canoga Park, CA 91304
No. of

Copies

W. S. Bennett/Paul Hagan

Rockwell International

Rocky Flats Plant

P.0. Box 464

Golden, CO 80401

4 Organic and Electronic Dept. 5810

Sandia Laboratories

Albuquerque, NM 87185

R. G. Kepler

D. R. Anderson

0 . E. Jones

W. Weart

D. E. Harrison

Westinghouse Electric Corp.

P.0. Box 355

Pittsburgh, PA 15230

P. B. Macedo

Keane Hall

Vitreous State Laboratory

The Catholic University of America

Washington, DC 20017

R. G. Post

College of Engineering

University of Arizona

Tucson, AZ 85721

L. L. Hench

Dept. of Materials Science and Engineering

University of Florida

Gainesville, FL 32611

Dr. Hayne Palmour II I

2140 Burlington Engineering Laboratories

North Carolina State University

Raleigh, NC 27607 
No. of

Copies

\section{ONSITE}

4 DOE Richland Operations Office
P. A. Craig
R. E. Gerton
H. E. Ransom
0 . J. Elgert

2 Rockwell Hanford Operations

I. E. Reep

D. D. Wodrich

UNC United Nuclear Industries

F. H. Bouse

Westinghouse Hanford Company

A. G. Blasewitz
No. of

Copies

45 Pacific Northwest Laboratory

S. M. Barnes

W. J. Bjorklund

H. T. Blair

W. F. Bonner

R. A. Brouns

J. L. Buelt

T. D. Chikalla

R. D. Dierks

C. R. Hann

M. S. Hanson

L. K. Holton

J. H. Jarrett

S. E. King

D. E. Knowlton

C. A. Knox

W. L. Kuhn

L. T. Lakey

D. E. Larson

R. P. Marshall

J. L. MCE lroy

G. B. Mellinger

J. E. Mendel

J. E. Minor/R. E. Nightingale

R. D. Nelson

J. M. Perez, Jr. (10)

R. D. Peters

A. M. Platt

W. A. Ross

W. R. Wiley

Technical Information (5)

Publishing Coordination (GO) (2) 